\title{
Temporal and spatial variations in tectonic subsidence in the Iberian Basin (eastern Spain): inferences from automated forward modelling of high-resolution stratigraphy (Permian-Mesozoic)
}

\author{
J.D. Van Wees ${ }^{\mathrm{a}, *}$, A. Arche ${ }^{\mathrm{b}}$, C.G. Beijdorff ${ }^{\mathrm{a}}$, J. López-Gómez ${ }^{\mathrm{b}}$, S.A.P.L. Cloetingh ${ }^{\mathrm{a}}$ \\ " Faculteit der Aardwetenschappen, Vrije Universiteit, De Boelelaan 1085, 1081 HV Amsterdam, Netherlands \\ ${ }^{b}$ Facultad de Ciencas Geológicas, Instituto de Geología Económica, Universidad Complutense de Madrid, 28040 Madrid, Spain
}

\begin{abstract}
By subsidence analysis on eighteen surface sections and 6 wells, which cover large part of the Iberian Basin (E Spain) and which are marked by high-resolution stratigraphy of the Permian, Triassic, Jurassic and Cretaceous, we quantify the complex Permian and Mesozoic tectonic subsidence history of the basin. Backstripping analysis of the available high resolution and high surface density of the database allows to quantify spatial and temporal patterns of tectonically driven subsidence to a much higher degree than previous studies. The sections and wells have also been forward modelled with a new 'automated' modelling technique, with unlimited number of stretching phases, in order to quantify variations in timing and magnitude of rifting. It is demonstrated that the tectonic subsidence history in the Iberian Basin is characterized by pulsating periods of stretching intermitted by periods of relative tectonic quiescence and thermal subsidence. The number of stretching phases appears to be much larger than found by earlier studies, showing a close match with stretching phases found in other parts of the Iberian Peninsula and allowing a clear correlation with discrete phases in the opening of the Tethys and Atlantic.
\end{abstract}

Keywords: Spain; Iberian Basin; subsidence analysis; tectonics

\section{Introduction}

The Iberian Ranges are part of an intracontinental fold chain in the northeast of the Iberian microplate, which formed from Tertiary inversion of the Iberian intracratonic basin. The whole of the chain has the shape of an elongated triangle with its base along the Mediterranean coast and its apex pointing northwest (see Fig. 1). The formation and inversion of the Iberian Basin is characterized by a complex post-

\footnotetext{
* Corresponding author. Tel.: +31 020 4447323; E-mail: weej@geo.vu.nl
}

Variscan history of lithospheric deformation, which is intimately linked to the opening and closure of the Tethys and the Atlantic oceans (e.g. Vegas and Banda, 1982; Sopeña et al., 1988; Ziegler, 1990). The Iberian Basin originated in Permian times, when localized basins developed under influence of intense wrenching of the crust due to the dextral shear movement between Africa and Laurasia. Subsequently, localized Permian basins were joined together in the Triassic when a main phase of stretching took place with deep basement faults accommodating the extension (Vegas and Banda, 1982; Sopeña et al., 1988). Subsidence studies quantifying the tectonic compo- 


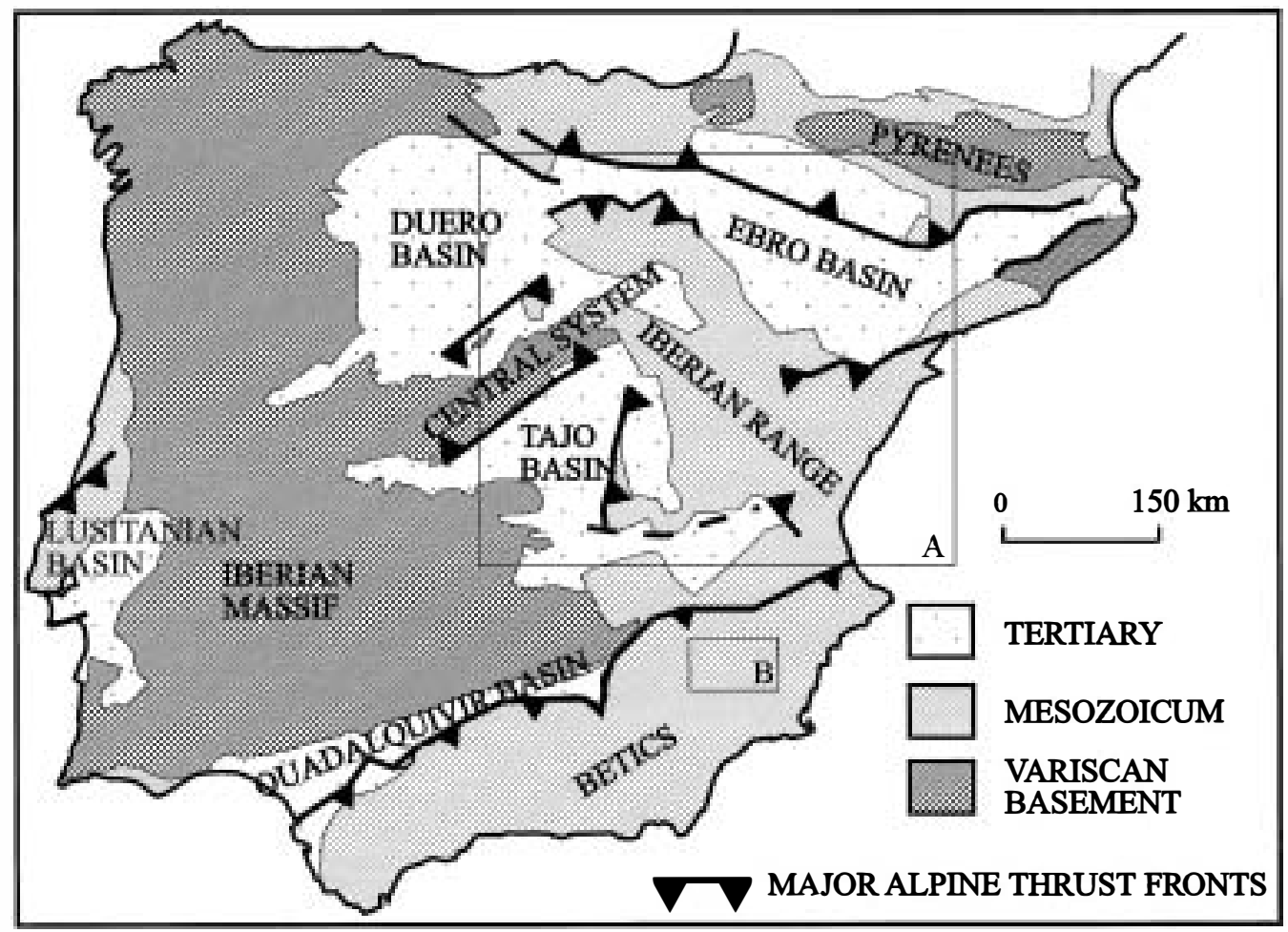

Fig. 1. Tectonic sketch map of the Iberian Peninsula (from Van Wees and Cloetingh, 1994). Box $A$ depicts area given in Fig. 2, box $B$ depicts area studied by Peper and Cloetingh (1992).

nent of the vertical movements indicate that this is a main phase of increased subsidence rates marked by lithospheric stretching factors of 1.1-1.3 (Salas and Casas, 1993; Van Wees and Stephenson, 1995; Arche and López-Gómez, 1996). In Early Jurassic and Middle Jurassic times subsidence rates relatively decrease and clear indications for faulting are absent, suggesting tectonic quiescence. Late Jurassic and (Early) Cretaceous times are clearly marked by tectonic activity resulting in (sub) basin formation marked by stretching factors with a magnitude locally up to the Triassic stretching (Salas and Casas, 1993; Van Wees and Stephenson, 1995). Convergent movements of Eurasia with respect to Africa (Roest and Srivastava, 1991), from the Late Cretaceous onward, resulted in folding and shortening of the Iberian Basin. Alpine deformation in this area has been mild compared to the pervasive thrusting and foreland basin formation associated with the Pyrenees and the Betic Cordilleras (e.g. Van Wees et al., 1992; Muñoz, 1992).

As indicated above, earlier quantifications on the
Iberian Basin subsidence have shed much light on its tectonic evolution (Salas and Casas, 1993; Van Wees and Stephenson, 1995; Arche and López-Gómez, 1996). However detailed quantitative insights in the Iberian Basin evolution are strongly limited because (1) these studies are based on small data sets (4, resp. 10 and 6 wells), (2) the datasets used are mostly marked by course stratigraphic age resolution, hampering identification of the multistage stretching history from the subsidence data, (3) forward modelling techniques are limited to a restricted number of stretching phases, at most three in Van Wees and Stephenson (1995). Clearly such analyses are not capable of revealing in great detail complex spatial and temporal variations in subsidence patterns which can be expected at the crossroads of the Tethys and Atlantic, and consequently hamper clear correlations with studies at the margins of Iberia and other regions in Europe.

For these reasons we quantify the complex Permian and Mesozoic tectonic subsidence history of 


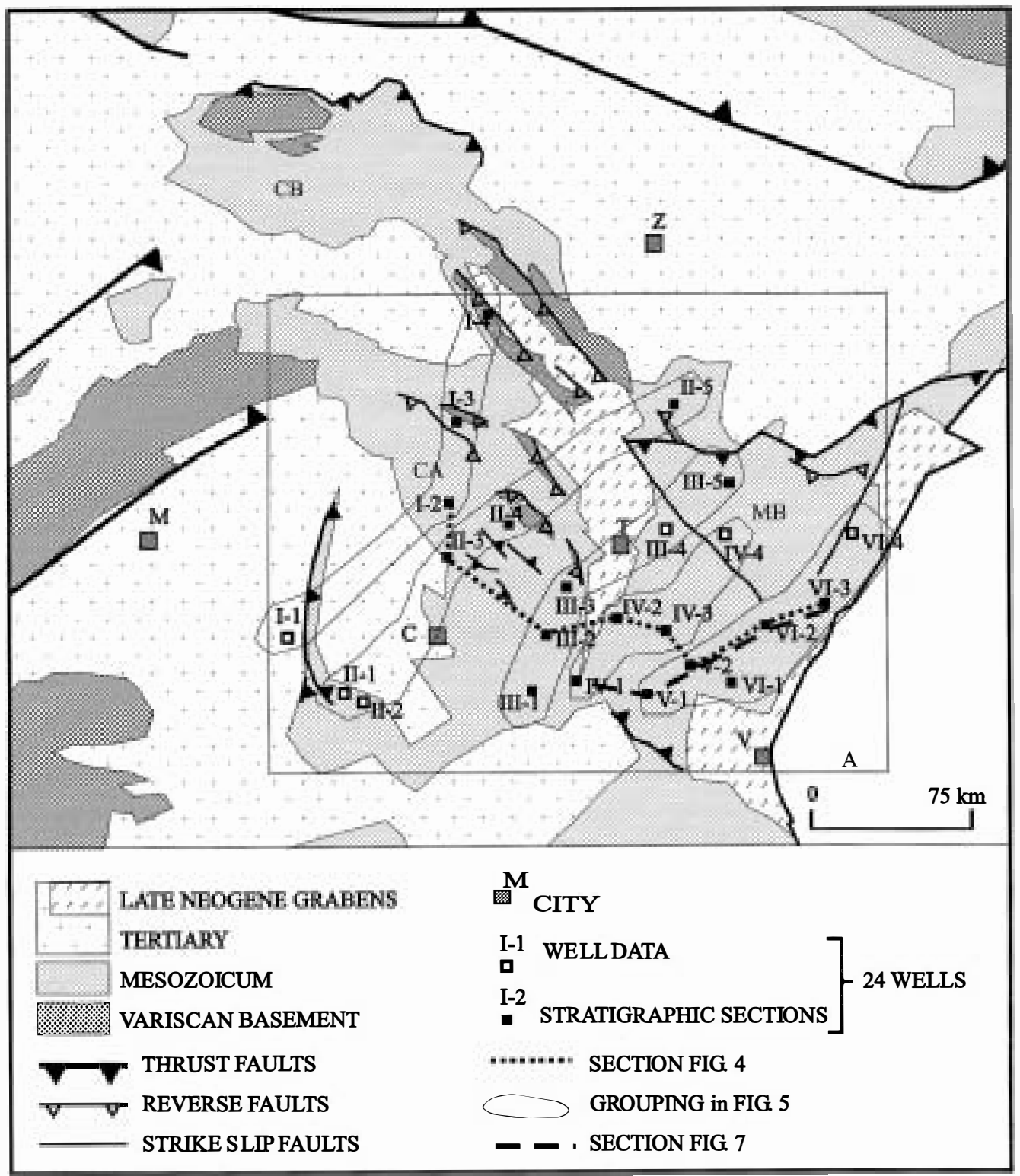

Fig. 2. Structural map of the Iberian Range and adjacent areas, corresponding to the converted Iberian Basin (modified from Van Wees and Cloetingh, 1994). Palaeogeographic domains of the Iberian Basin are the Cameros Basin $(C B)$, Central Area (CA), and Maestrat Basin $(M B)$. Locations of analysed stratigraphic sections and wells are indicated by a combination of roman and arabic numbers. $I-1$, $I I-1, I I-2, I I I-4, I V-4$ and $V I-4$ are wells, the rest are stratigraphic surface sections. In the remainder of the text we refer to all as wells. $C$ = Cuenca; $M=$ Madrid; $V=$ Valencia; $Z=$ Zaragoza. Box $A$ corresponds with boundaries of maps in Figs. $3,6,12$ and 13 .

the Iberian Basin, using a large and detailed stratigraphic database, consisting of eighteen surface sections and six wells, which covers the Central Area and the Maestrat Basin in the Iberian Basin (Figs. 2 and 3). For clarity, in the remainder of the text we refer to these as wells. The database builds on extensive work on high-resolution stratigraphy of the Permian and Triassic by co-authors Arche and López-Gómez (Arche and López-Gómez, 1989, 1996; López-Gómez and Arche, 1992a,b, 1993, 1997) 


\section{Total Sediment Thickness (m)}

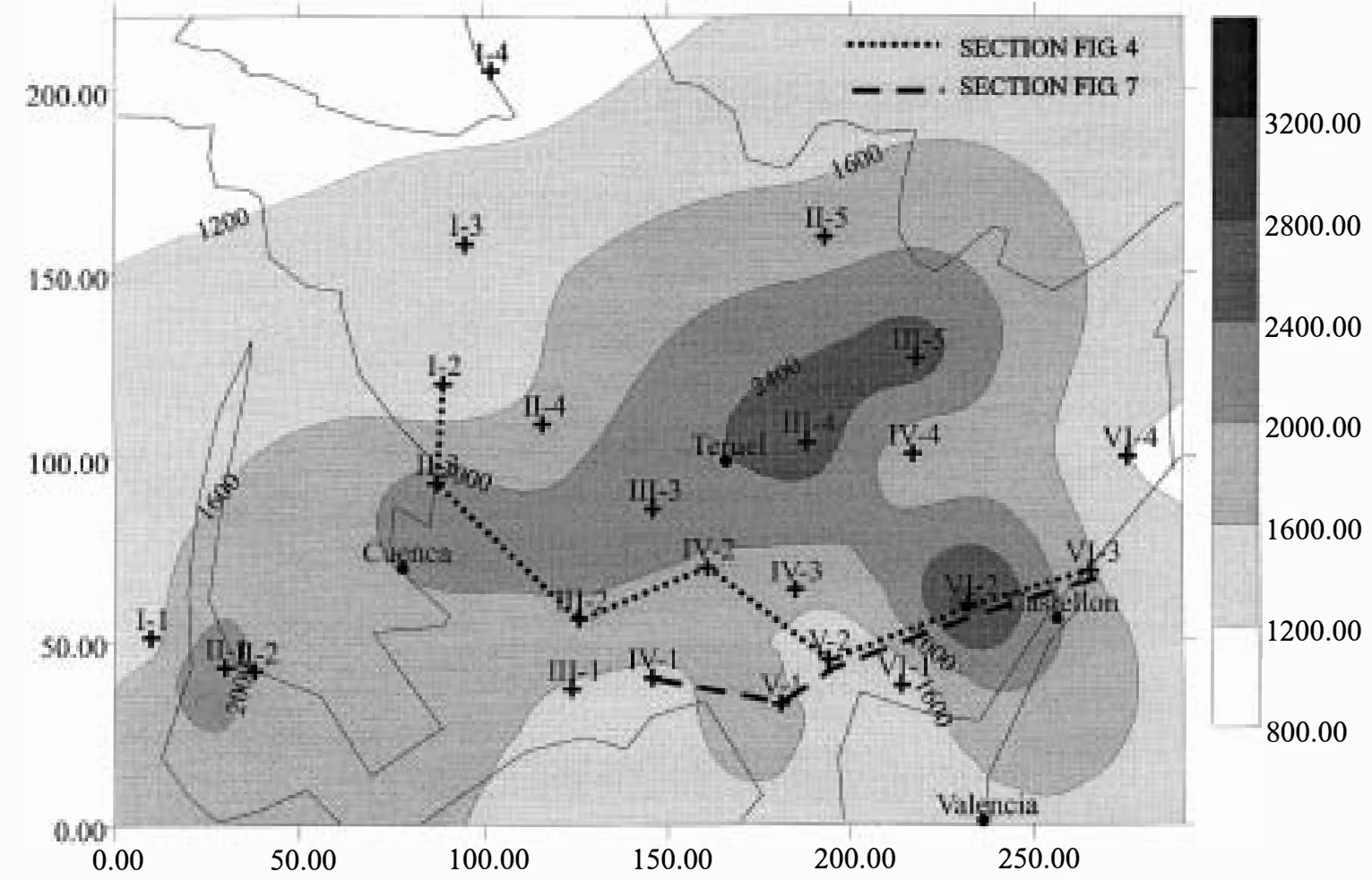

Fig. 3. Map view of the total sediment thickness (m) from Permian to Present, based on analysed surface sections and wells. Solid lines indicate approximate outline of inverted Iberian Basin (Fig. 2) and coastline.

and on detailed documentation of Jurassic and Cretaceous sediments (e.g. Goy and Suarez Vega, 1983; Rincón et al., 1983; Vilas et al., 1983). The western part of the studied area includes the area studied by Van Wees and Stephenson (1995), whereas the northeastern part includes the Maestrat Basin studied by Salas and Casas (1993). Furthermore, the surface density and depth range of the 24 wells (Fig. 3) allows to analyse spatial patterns of subsidence, lacking in previous studies.

The backstripped curves have been forward modelled with a new 'automated' modelling technique, with unlimited number of stretching phases, in order to quantify variations in timing and magnitude of rifting. We will show that the tectonic subsidence history in the Iberian Basin is one of pulsating periods of stretching intermitted by periods of relative tectonic quiescence and thermal subsidence. The number of stretching phases appears to be much larger than found by the aforementioned earlier studies, showing a close match with stretching phases found in other parts of the Iberian Peninsula and allowing a clear correlation with discrete phases in the opening of the Tethys and Atlantic.

\section{Permian and Mesozoic stratigraphic evolution}

Most Permian and Mesozoic stratigraphic horizons can be easily correlated throughout the basin and are marked by high-resolution relative age data. The chronostratigraphic diagram in Fig. 4 shows these stratigraphic correlations for one third of the wells through the centre of the basin. Table 1 gives references and generally used formation names. The absolute stratigraphic ages were derived by applying the Harland et al. (1990) time scale to the local stratigraphic scheme. 


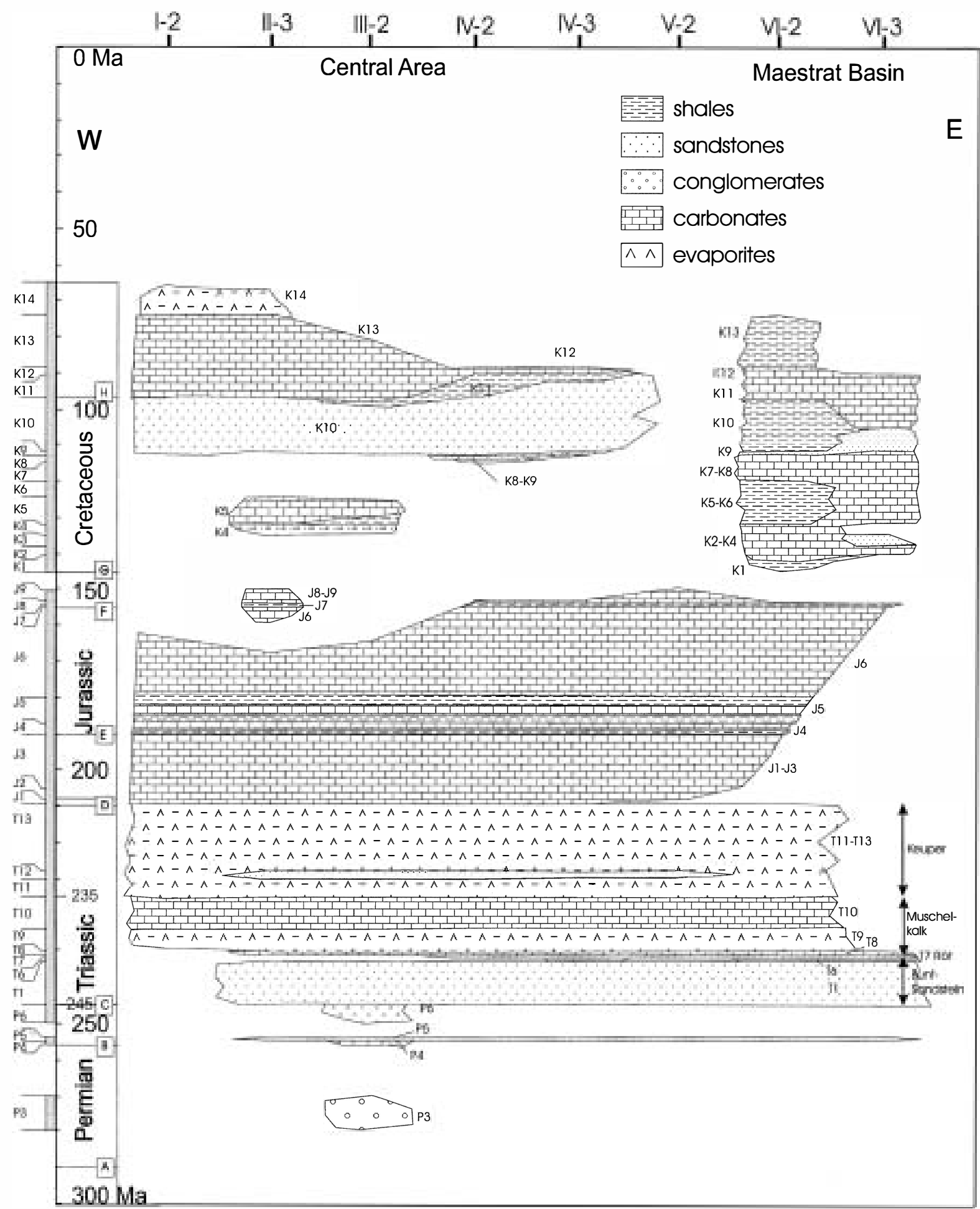

Fig. 4. Stratigraphic column of the SE Iberian Ranges (compiled from analysed surface sections and well data from López-Gómez and Arche, 1992a,b, 1993). 
Table 1

Ages of formations

\begin{tabular}{|c|c|c|c|}
\hline Code & Stage & $\begin{array}{l}\text { Age (1) } \\
\text { (Ma) }\end{array}$ & Formation \\
\hline K14 & [Maastrichtian] & $74-65$ & Calizas de la Sierra de la Pica (5) \\
\hline $\mathrm{K} 13$ & [Campanian-Coniacian] & $88.5-74$ & Calizas Dolomiticas del Pantano de la Tranquera (2) \\
\hline $\mathrm{K} 12$ & [Turonian] & $90.5-88.5$ & $\begin{array}{l}\text { Dolomías de la Ciudad Encantada + Calizas y } \\
\text { Margas de Casa Medina (2) }\end{array}$ \\
\hline K11 & [Cenomanian] & $97-90.5$ & Calizas y Margas de Mosqueruela (5) \\
\hline $\mathrm{K} 1 \bullet$ & [Albian] & $112-97$ & Arenas de Utrillas (5) \\
\hline K9 & [Aptian) & $113-112$ & Calizas de Benasal (5) \\
\hline K8 & (Aptian) & $115-113$ & Calizas de Benasal (5) \\
\hline K7 & (Aptian) & $120-115$ & Calizas de Villarroya de Pinares (5) \\
\hline K6 & (Aptian) & $124.5-120$ & Margas de Forcall (5) \\
\hline K5 & [Barremian] & $132-124.5$ & Calizas y Margas de Ares de Maestre (5) \\
\hline K4 & [Hauterivian] & $135-132$ & Margas de Mirambell (5) \\
\hline K3 & [Valangian] & $138-135$ & Calizas y Margas de Vallivana (5) \\
\hline $\mathrm{K} 2$ & (Valangian) & $140.5-135$ & Calizas y Margas de Vallivana (5) \\
\hline $\mathrm{K} 1$ & [Berriasian] & $145-140.5$ & Calizas de Vallivana (5) \\
\hline J9 & (Tithonian. Kinmeridgian) & $153-150$ & Calizas con Oncolitos de Higueruelas (3) \\
\hline J8 & (Kimmeridgian) & $154-153$ & Ritmita Calcárea de Loriguilla (3) \\
\hline J7 & (Kimmeridgian Oxfordian) & $155-154$ & Margas de Sot de Chera (3) \\
\hline $\mathrm{J} 6$ & (Oxfordian-Toarcian) & $180-155$ & Lower and medium part of Carbonatada de Chelva (3) \\
\hline J5 & (Toarcian) & $187-180$ & Margas y Calizas de Turmiel (3) \\
\hline $\mathrm{J} 4$ & [Pliensbachian] & $190-187$ & Calizas de Barahona/Margas del Cerro del Pez (3) \\
\hline $\mathrm{J} 3$ & (Pliensbachian, Sinemurian. Hettangian) & $205-190$ & Calizas y Dolomias de Cuevas Labradas (3) \\
\hline $\mathrm{J} 2$ & (Hettangian) & $208-205$ & Camiolas de Cortes de Tajuña (3) \\
\hline $\mathrm{J} 1$ & [Rhaetian] & $209.5-208$ & Dolomias Tableadas de Imón (3) \\
\hline $\mathrm{T} 11-\mathrm{T} 13$ & [Norian Carnian] & $235-209.5$ & 'Facies Keuper': anhydrites and mudstones (4) \\
\hline $\mathrm{T} 10$ & [Ladinian] & $238-235$ & Dolomías y Calizas de Cañete (4) \\
\hline T9 & (Ladinian. Anisian) & $240-238$ & Arcillas, Margas y Yesos del Mas (4) \\
\hline $\mathrm{T} 8$ & (Anisian) & $24 \bullet .5-24 \bullet$ & Dolomías de Landete (4) \\
\hline $\mathrm{T} 7$ & (Anisian) & $240.7-24 \bullet .5$ & Arcillas, Limos y Margas de Marines (4) \\
\hline $\mathrm{T} 6$ & (Anisian] & $241-240.7$ & Lutitas y Areniscas de Eslida (4) \\
\hline $\mathrm{T} 1$ & [Scythian] & $245-241$ & Areniscas del Cañizar (4) \\
\hline P6 & Latest Permian & $250-245$ & Conglomerados de $\mathrm{Hoz}$ de Gallo (6) \\
\hline P5 & Saxonian & $255-254$ & Limos y Areniscas de Alcotas (4) \\
\hline $\mathrm{P} 4$ & Saxonian & $256-255$ & Conglomerados de Boniches (4) \\
\hline P3 & Autunian & $280-27$ & Brechas de Tabarreña (4) \\
\hline $\mathrm{P} 1-\mathrm{P} 2$ & Autunian & $290-280$ & Capas de la Errnita (6) \\
\hline
\end{tabular}

References: (1) Harland et al., 1990; (2) Rincón et al., 1983; (3) Goy and Suarez Vega, 1983; (4) López-Gómez and Arche, 1993; (5) Canérot et al., 1982; (6) Ramos, 1979.

\subsection{Permian and Triassic (excluding Rhaetian)}

The sediments of Permian and Triassic age represent the beginning of the Alpine cycle of sedimentation in the Iberian Basin; they have been dated by means of different fossil groups and can be correlated throughout the basin as shown in the chronostratigraphic diagram in Fig. 4 for one third of the 24 wells studied in this paper.
The Permian and Triassic stratigraphy has been extensively described, among others, by Sopeña et al. (1988) and López-Gómez and Arche (e.g. Arche and López-Gómez, 1989, 1996; López-Gómez and Arche, 1992a,b, 1993) and we adopt the interpretations and correlations of the latter authors (Fig. 4, Table 1).

The Permian sediments are subdivided into three unconformity-bounded sequences (P1-P6), not al- 
ways easy to correlate along the Iberian Basin. The lowermost one (P1-P3) or 'Autunian Facies', consists of alluvial fan, lacustrine, volcanic and volcanoclastic and slope scree materials deposited in small, kilometric, isolated basins in the northwestern and central parts of the basin; the middle sequence (P4-P5) or 'Saxonian Facies' consists of conglomerates of alluvial fan and braided river origin, present only in the central part of the basin and red mudstones and sandstones deposited over a much broader area, deposited in distal braided rivers and shallow lakes; the uppermost sequence (P6), which forms the base of the 'Buntsandstein Facies', consists of conglomerates of alluvial fan origin succeeded by sediments of Triassic age.

The Permian-Triassic boundary is not marked by unconformities and lies somewhere inside the basal sandstone formation ( $\mathrm{T} 1$ ); the Triassic sediments broadly correspond to the 'Germanic Triassic megasequence' found in northwest Europe, with the typical Buntsandstein, Muschelkalk and Keuper Facies. In the Triassic four sequences have been identified in the Iberian Basin, bounded by hiatuses.

The lowest sequence consists of two intervals, sandstones ( $\mathrm{T}$ l) and sandstones and mudstones (T6), interpreted as sandy braided river deposits and distal braided meandering and ephemeral river deposits; overlying 'Röt' and 'lower Muschelkalk Facies' consist of two formations: mudstones and marls (T7) and dolomites (T8) interpreted as intertidal and shallow shelf deposits. They are succeeded by the 'upper Muschelkalk Facies' with clays and gypsum (T9) and dolomites (T10) also of intertidal and shallow shelf origin. The uppermost sequence or 'Keuper Facies' consists of clays and evaporites (T11), sandstones (T 12) and evaporites (T13) all of them of shallow marine and coastal origin.

\subsection{Jurassic (including Rhaetian)}

For the Jurassic sediments of the Iberian Basin we adopted the stratigraphic subdivision synthesized by Goy and Suarez Vega (1983) from different authors (Goy et al., 1976; Gómez, 1979; Gómez and Goy, 1979, among others). Most of the formations in this subdivision are characterized by very uniform lithological development.

The upper boundary of the Triassic supersequence is an unconformity, very well observed in the north Iberian Basin (San Román and Aurell, 1992). This surface is planar to uneven, located between two shallow marine to intertidal dolomitic units ( $\mathrm{Jl}$ and J2, Table 1). This important period of erosion before the deposition of the J2 Liassic carbonate unit overlies a partly dismantled Triassic sequence (Keuper and Muschelkalk) and occasionally reaching down the top of the Buntsandstein in the eastern Iberian Ranges (Roca and Guimerá, 1992). The TriassicJurassic boundary is traditionally placed in this unconformity (Goy et al., 1976; Gómez, 1979). Therefore the $\mathrm{Jl}$ is actually Triassic in age (Rhaethian), although it should be noted that the age of its upper part is still a matter of discussion. The inclusion in the Jurassic sequence follows traditional stratigraphic subdivisions, based on a sharp lithological transition from Keuper clays and evaporites to Jl and Jurassic carbonates (Table 1).

The lowermost part of the subdivision adopted here for the Jurassic units includes three well developed formations of carbonates, J1 to J3. J1 consists of well stratified (oolitic) dolomites followed by poorly stratified limestones and brecciated dolomites in J2, while J3 consists of thickly banked limestones and dolomites. These are interpreted as shallow shelf (close platform) deposits that evolved until the early Pliensbachian.

On the top of J3 a new sequence (Pliensbachianearly Oxfordian) constituted by three units (J4 to J6) appears. The lower unit (J4) is uniformly developed and consists of marls with overlying undulatingly stratified bioclastic limestones that evolves to a less uniform unit of rhythmic pelagic marls and limestones, containing volcanics (J5) and interpreted as open platform to open ammonitic marine deposits (Goy and Martínez, 1990). The overlying J6 unit consists of carbonates of laterally varying facies consisting of open marine sediments including the Toarcian-Oxfordian. In the central part of the Iberian Basin in the upper part of shallowing sequences deposited during the Aalenian-early Bajocian J6 shows evidence of uplift and karstification (Fernández-López and Gómez, 1990). Subsequently, during the Bathonian-Callovian, in the northwest of the Iberian Range, tectonic destabilisation caused a structural palaeogeographical framework with very variable subsidences manifested in two big se- 
quences in J6 limited by widespread unconformity horizons (Wilde, 1990) and sometimes with significant ammonite faunas (Thierry and Wilde, 1990). The top of J6 is marked by the uniform deposition of a condensed section of ferruginous oolite limestones, marking a pronounced regression culminating in a regional hiatus in the late Callovian-early Oxfordian (Álvaro et al., 1979)

The overlying formation (J7) consists of open marine ammonite-bearing marls and marly limestones (except for the north, where it consists of detritic deposits) indicating a widespread transgression during the middle-late Oxfordian. Subsequently, during the early Kimmeridgian when accommodation space increased considerably with significant relative sea-level rise, successive low-angle slope carbonate ramps were developed, where sediments were deposited mainly to the east. The transition between these ramps was punctuated by lower-order relative sea-level changes generating unconformities clearly detected in the proximal areas of the ramps (Aurell and Meléndez, 1993). Later in the Kimmeridgian a distally steepened ramp was formed, including thin-bedded lime-mudstones, sponge buildup and anoxic basinal marls (Salas and Casas, 1993) resulting in a sudden drowning of the Oxfordian homoclinal ramp. This transgression was rapidly followed by a general regression manifested in marly limestones intercalated with calcareous limestone sediments (J8) and indicating decreasing waterdepths compared to J7. The topmost formation (J9) consists of stratified massive limestones, which can contain oolites and detritic elements. These sediments are interpreted to be submarine and closed platform deposits. The J7-J9 is the typical transgressiveregressive sequence of a carbonate platform of which the vertical formation transitions also occur laterally at the platform margins (Martinez del Olmo, 1996).

\subsection{Cretaceous}

Early Cretaceous times are characterised by relatively strong lateral and temporal variations in sedimentation marked by the evolution of palaeohighs and sub-basins and many hiatuses, respectively. Although sediments show very important lateral changes all along the Iberian Basin, in general, sequences can be identified in filling sub-basins and onlapping the structural highs, intermittent with the appearance of lacunae and stratigraphic discontinuities in the Cretaceous but also affecting up to the Jurassic basement (Vilas et al., 1983).

A first episode of differentiated subsidence took place during the Kimmeridgian-middle Berriasian (Aurell and Meléndez, 1993) or maybe Valanginian (Vilas et al., 1983). As a result, a shallow platform (Kl) was developed including extensive tidal flats fringed by marginal shoal banks (Viallard, 1973; Canérot, 1974; Salas, 1987; Aurell, 1991) that evolved subsequently to infra-supralittoral carbonate platform $(\mathrm{K} 2-\mathrm{K} 3)$. During the Valanginian, an important regional migration of fresh-water lenses took place in a basinward direction (Salas and Casas, 1993) that resulted in significant diagenetic events of the exposed carbonate sequences.

Most of the Hauterivian sediments (K4), if preserved, were of continental origin (except in the Maestrat area). Although differentiated subsidence continued during the beginning of the Hauterivian, it decreased in respect to previous stages and extensive areas of the borders of the sub-basins were exposed and eroded (Fig. 4). The end of the Hauterivian corresponds with an unconformity where pre-existing rocks (Triassic and Jurassic) were affected by karstification, erosion and soil development (Vilas et al., 1983). The late Hauterivian-Barremian sequence (K5) was represented by shallow carbonate platforms with fresh-water discharge in the Maestrat area (up to $1000 \mathrm{~m}$ ) (Salas and Casas, 1993), but also terrigenous siliciclastic deposits (Weald facies) with some marine incursion, appeared in other sub-basins (Canérot, 1974; Meléndez, 1983; Salas, 1987; Salas and Martín-Closas, 1995). This sedimentation also resulted in hiatuses and unconformities, as Meléndez (1982) described for the Barremian of the central Iberian Basin.

Due to an important late Barremian regression, the Aptian sequence (K6-K9) started with an unconformity in the Maestrat area overlain by fluvial and deltaic environments. However, in the central part of the Iberian Basin, the sedim entary succession from the unconformity until the late Albian seems to be almost continuous (Meléndez, 1983), consisting of two sequences of transitional environments and some marine wedges, coming from the east, at their top. 
Albian sedimentation is mainly marked by fluvial sedimentation ( $\mathrm{Kl}$ ), except for the eastern parts. In most of the Iberian Basin, the early and most of the middle Albian was emergent. An important and local extensional tilting appeared during the middle Albian and structural highs separating subsiding subbasins marked by generally eastward tilting formed, resulting in lateral transition from fluviatile sedimentation to deeper-water sediments in the sub-basins (Vilas et al., 1983). From late Albian times the sedimentation rates decreased considerably. During the late Albian, the area was again emerged and mainly fluvial deposits (Fig. 4) were deposited (Ruiz, 1993).

The late Albian-early Cenomanian deposition $(\mathrm{K} 1 \mathrm{-}-\mathrm{K} 11)$ in the Iberian Basin is composed of a complex alternation of continental (northwestward), coastal and marine (southeastward) facies that are arranged mainly in transgressive and deepeningupward sequences bounded by subaerial exposure surfaces or ferruginous crust (García et al., 1996).

The late Cenomanian started with a transgressive period that caused a complete homogenization (K12) with the installation of a Turonian carbonate platform tilted northward where open marine carbonates were deposited. After a regressive tendency, that culminated in local interruption in sedimentation, the Coniacian and most of the Santonian started with an extensive internal carbonated platform reaching the maximum development in the late Santonian (K13) (Alónso et al., 1987; Floquet, 1991). A second stage of regressive tendency was developed during the late Campanian. As a result Maastrichtian sediments (K14) represent extensive plains near the coastal line, evolved with permanent marshes and lakes that contained carbonate sediments (Fig. 4).

\section{Subsidence analysis}

In order to quantify the tectonic component of subsidence of the basin the backstripping technique was used (Steckler and Watts, 1978; Bond and Kominz, 1984). For this purpose, air-loaded tectonic subsidence has been calculated from the stratigraphic records adopting local isostasy to correct for the effect of sediment loading. Corrections for compaction were made by using porosity-depth relationships on the basis of the observed lithologies using standard mean exponential relations and material parameters (cf. Sclater and Christie, 1980).

The effects of palaeobathymetry have been taken into account, using sedimentary facies and faunal content. It is inferred that depths never reached greater values than $150 \mathrm{~m}$ (Jurassic and Early Cretaceous), with waterdepths of $0-30 \mathrm{~m}$ prevailing. Errors in waterdepths are likely to be less than 50 m. During Early Cretaceous times, large areas became temporarily emerged (i.e. Rincón et al., 1983), leading to an erosional hiatus over much of the area. The associated tectonic subsidence and subsequent uplift have not been quantified. In the Tertiary continental sedimentary conditions prevailed. Unknown topographic elevations at the time of deposition, at present ranging between $12000 \mathrm{~m}$, are not taken into account. This would most likely alter the Tertiary part of the backstripping calculations. Eustatic sea-level fluctuations (Haq et al., 1987), estimated up to $100 \mathrm{~m}$, and effects of intraplate stress (Cloetingh et al., 1985) have not been incorporated in the analysis

Tectonic subsidence curves resulting from the backstripping calculations are shown in Fig. 5. For clarity of display, errors related to possible extreme variations in adopting porosity-depth relationships (Bond and Kominz, 1984) and estimated palaeowaterdepths are not shown. Variations in these could accumulate in deviations in tectonic subsidence not larger than $150 \mathrm{~m}$. For the Tertiary large errors may be involved in estimating tectonic subsidence, because of the absence of palaeotopographic data, as mentioned before

Fig. 5 gives an overview of the tectonic subsidence curves for all the analysed wells. The curves are roughly grouped in five NE-SW 'sections', the first being the most northwestern and the last being the most southeastern (Fig. 2). The tectonic subsidence curves show episodes of increased subsidence rates intermitted with phases of slower subsidence, uplift and hiatuses (horizontal lines). Changes in subsidence rate can, in most cases, be correlated over the entire study area.

Fig. 6 gives the tectonic subsidence for time intervals which generally contain one episode of rapid subsidence and subsequent slower subsidence in map views to illustrate spatial relationships. For each episode of rapid subsidence we discuss the 

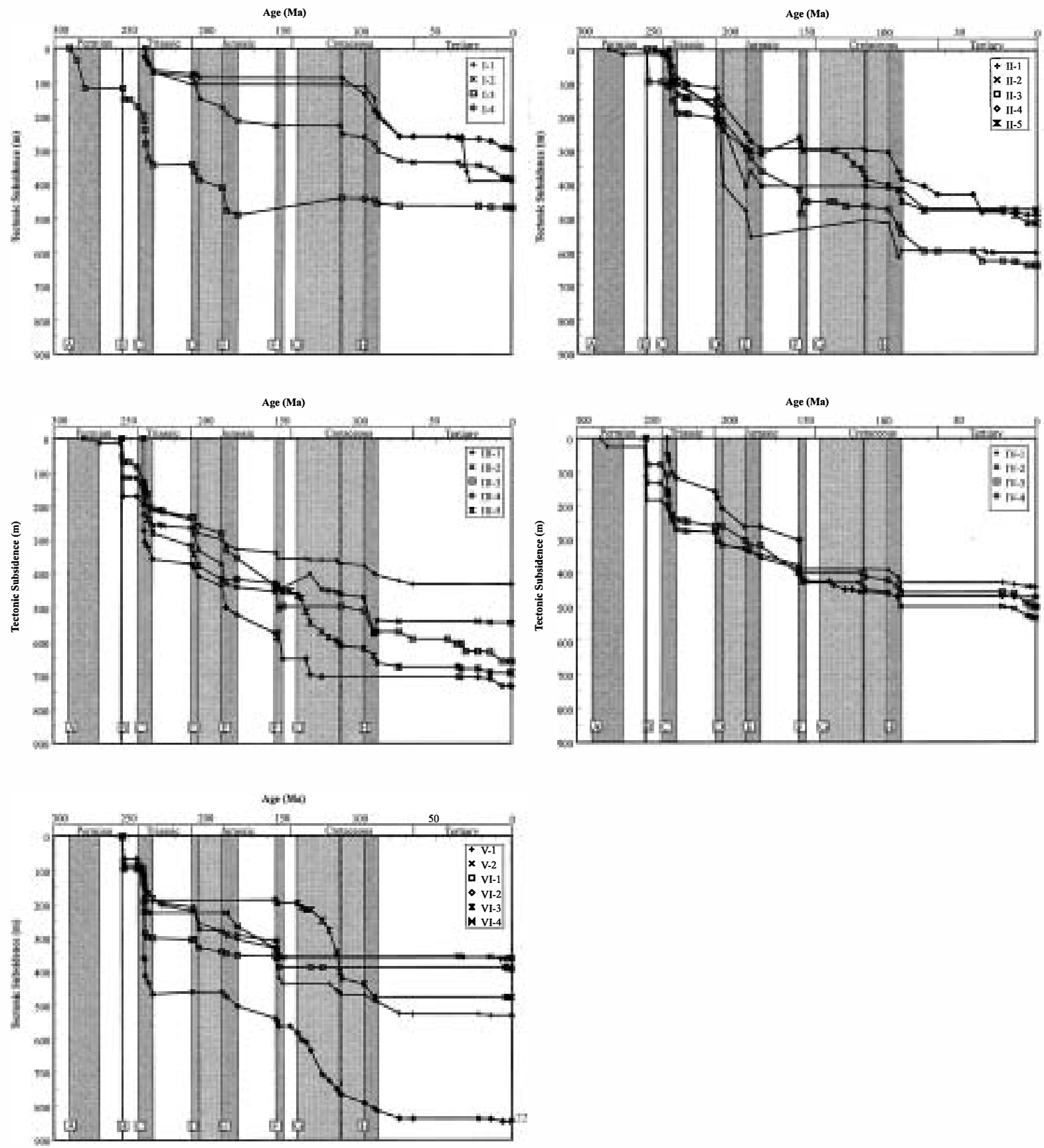

Fig. 5. Backstripped air-loaded tectonic subsidence $(\mathrm{m})$ for 24 stratigraphic sections in the Iberian Ranges. Locations are indicated in Figs. 2 and 3) A subdivision has been made into five groups to represent the data. The groups are roughly NE-SW sections over the axis of the basin. With darker shaded areas we indicate regional (apparent in most groups) episodes of relatively rapid subsidence with clear beginning and ending times, and lighter shades correspond with periods of relatively rapid subsidence with less well defined beginning and ending times. Locations of sections are given in Fig. 2. 
spatial and temporal relationships of the 24 wells in terms of tectonics and documented fault activity (e.g. Fig. 7) and we relate these with the regional tectonic history of Iberia, and episodes in the opening of the Tethys and Atlantic oceans (Fig. 8)

\subsection{Permian}

Rotliegendes 290-256 Ma (P1-P3). Only wells I-3, II-4, III-2, IV-1 show subsidence, with well I-3 having the largest tectonic subsidence value, namely $100 \mathrm{~m}$, while the other three wells have values of about $20 \mathrm{~m}$. Well I-3 is tectonically active from 290 to $280 \mathrm{Ma}$, IV-1 from 285 to $280 \mathrm{Ma}$ and II-4 and III-2 from 280 to 270 Ma. Spatially the wells which show subsidence align along a NW-SE trend. The maximum depocentres (I-3, IV-1) may form two small local basins on the map. This phase of Early Permian rapid tectonic subsidence most likely corresponds with the formation of small intermontane basins which were controlled by intense shearing of the crust by the right lateral motion of Africa compared to Laurasia (and Iberia) and superimposed vertical movements, i.e. isostatic adjustment of the crust (Vegas and Banda, 1982; Sopeña et al., 1988; Ziegler, 1990). Rapid tectonic subsidence is followed by a period of tectonic quiescence.

Zechstein 256-245 Ma (P4-P6). All wells show a phase of rapid tectonic subsidence from 256-254 Ma, except wells I-1, I-2, I-4, II-1, II-2, II-4 in the west, and III-5 and IV-4 in the northeast. Tectonic subsidence values range from $50 \mathrm{~m}$ in most wells to $170 \mathrm{~m}$ in well III-4. The depocentres in I-3 and IV-1 indicate a reactivation of the two depocentres identified for the Rotliegendes. The southern depocentre shows a distinct deepening and widening compared to the Rotliegendes. Although the number of wells recording subsidence is limited, it appears that a NE-SW-trending basin (IV-1, IV-2, III-4) is formed with possibly a branch to the northwest. Rapid subsidence rates correspond with onset of Permo-Triassic rifting which is evident from the development of NW-SE-trending horst and graben structures, controlled by steeply dipping basement faults (Sopeña et al., 1988; Fig. 7). These faults originated in the late Variscan and reactivation is related to the extensional episodes that caused the opening and westward extension of the Tethys Ocean (Salas and Casas, 1993).
Slower subsidence values prevail during 254-245 $\mathrm{Ma}$, indicating a postrift phase.

\subsection{Triassic (excluding Rhaetian)}

Scythian-Norian 245-209.5 Ma (T1-T13). All wells record the Scythian-Ladinian phase of rapid subsidence which is highly pronounced, with subsidence values ranging from $70 \mathrm{~m}$ in well I-4 to 380 $\mathrm{m}$ in well VI-2. This indicates that rifting is now widespread, and most wells show tectonic subsidence values in the order of 100-200 m with highest values in the east. Beginning times vary from $241 \mathrm{Ma}$ in most wells to $245 \mathrm{Ma}$ in wells III-2, III-3, III-3 and IV-1. All wells indicate that rapid subsidence is most pronounced in the upper part of the 'Bundsandstein Facies' and 'Röt and lower Muschelkalk facies' sequences (241-240 Ma, T6-T8). The 'upper Muschelkalk Facies' sequence (240-235 Ma, T9-T10) indicates the onset of decelerated subsidence, although subsidence rates are still very high. The 'Keuper facies' sequence (235-209.5 Ma, T11-T13) is marked by slow subsidence rates. In the east of the area, wells VI-3 and VI-4 show hiatuses in the upper Muschelkalk and Keuper sequences. This results in slightly lower tectonic subsidence. The hiatus in well VI-3 lasts till $155 \mathrm{Ma}$, in wells VI-4 till $190 \mathrm{Ma}$. Spatial variations in subsidence (Fig. 8) indicate the occurrence of a relatively narrow NW-SE-trending basin in the east, most likely bounded by NW-SE-trending boundary faults. Earlier studies on the Triassic evolution (Sopeña et al., 1988) and more recent detailed studies on thickness variations on individual formations in the Triassic (e.g. López-Gómez and Arche, 1995; Arche and López-Gómez, 1996; Fig. 7) agree with this interpretation. These studies indicate that fault activity is mostly active during sedimentation of T1-T7, resulting in NE-SW-trending horst graben structures, in which additionally separation of grabens occur by NE-SW-trending transfer faults and already existent basement highs. According to these studies the depression in the southwest corresponds to another NW-SE fault bounded graben (Fig. 7). The existence of transfer faults may well explain the relatively abrupt NE-SW-trending boundary of NWSE-trending basins in Fig. 6. Already existent basement highs are most likely responsible for late onset of sedimentation in I-1, I-2, I-4 and IV-4. 
(A) Tectonic Subsidence 290-256 Ma

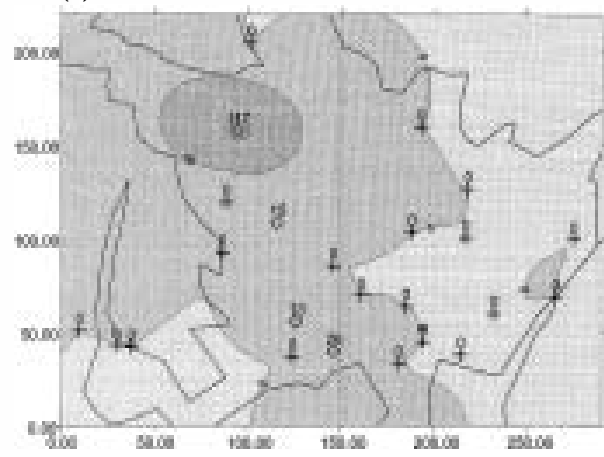

(C) Tectonic Subsidence 245-209.5 Ma

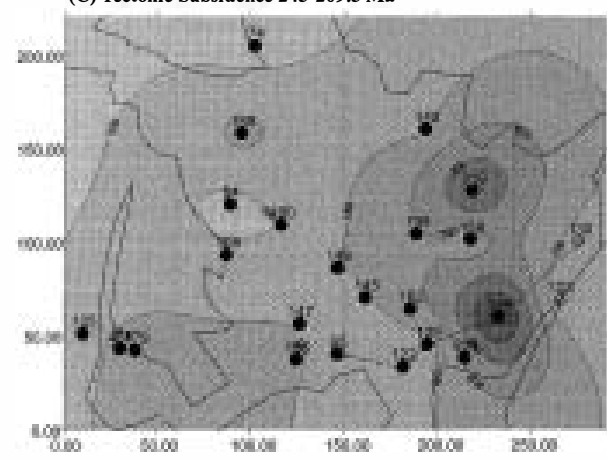

(E) Tectonic Subsidence 190-155 Ma

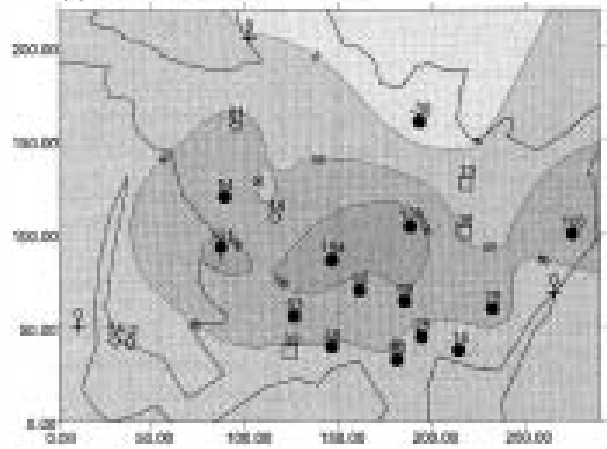

(G) Tectonic subsidence 146-97 Ma

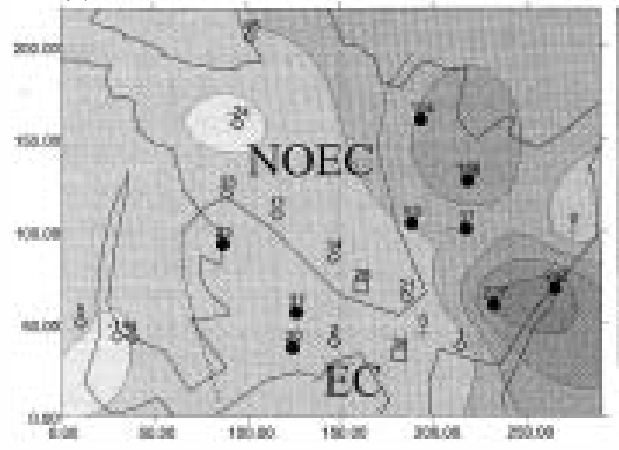

(B) Tectonic Subsidence 256-245 Ma
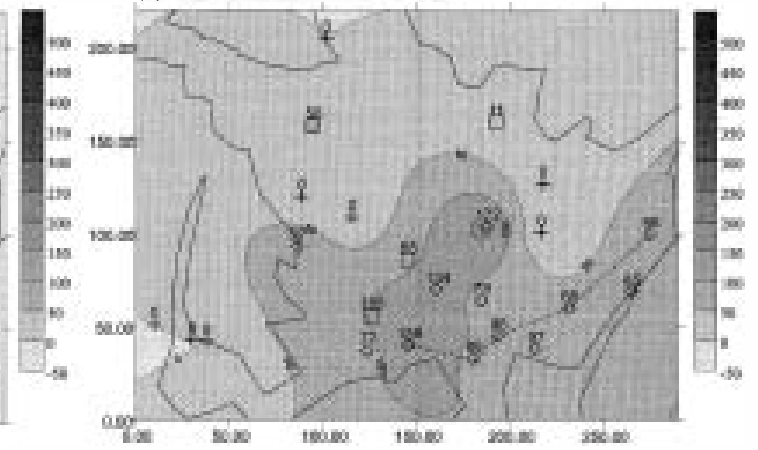

(D) Tectonic Subsidence 209.5-190 Ma
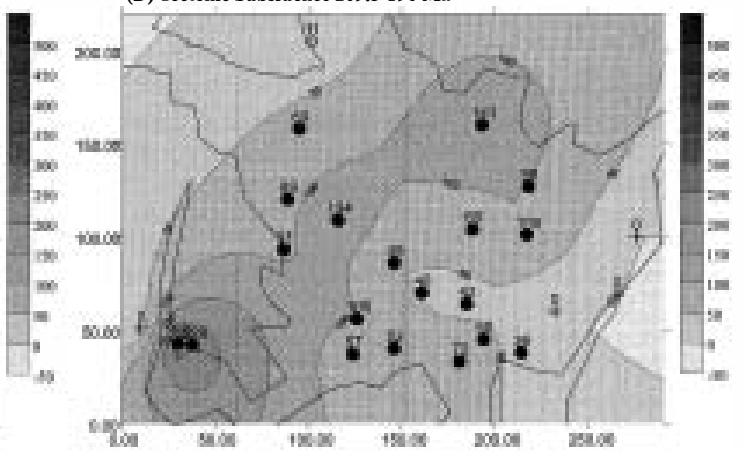

(F) Tectonic subsidence 155-146 Ma
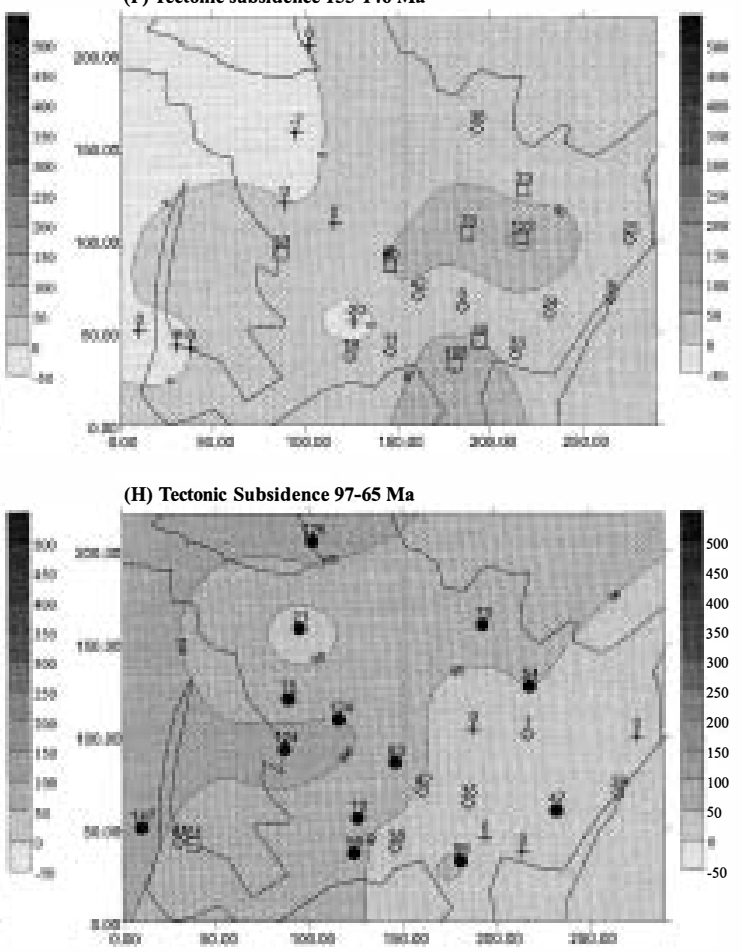


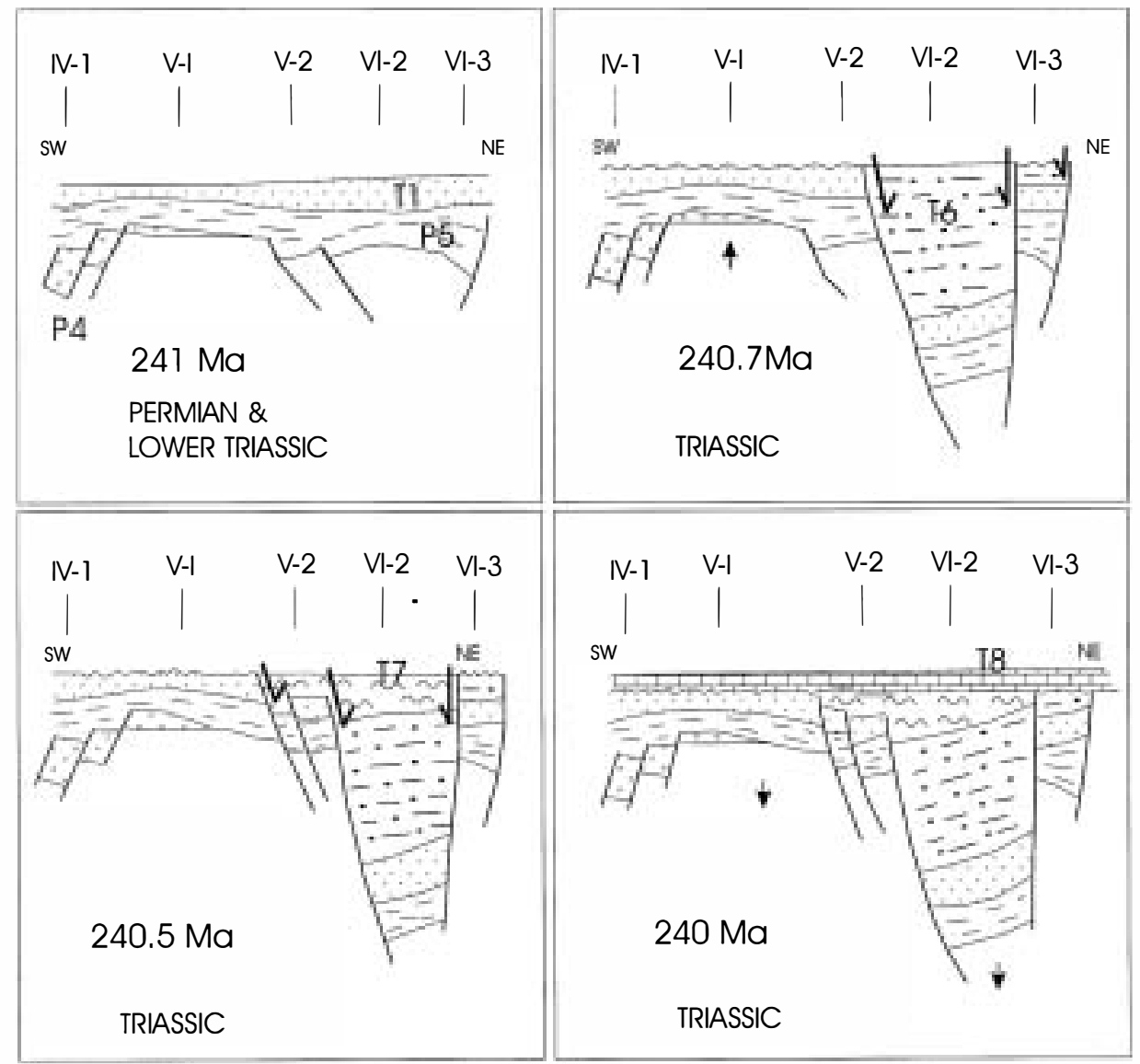

Fig. 7. Tentative SW-NE cross-section illustrating fault activity during Permo-Triassic basin formation (for location see Fig. 6B), based on well information and field mapping (modified after Arche and López-Gómez, 1996).

\subsubsection{Jurassic (including Rhaetian)}

Rhaetian-Sinemurian 209.5-190 Ma (J1-J3). All the wells except I-1, VI-2, VI-3 and VI-4 experience rapid subsidence. All the wells start rapid subsidence at $209.5 \mathrm{Ma}$. While in most wells increased subsidence is terminated at $205 \mathrm{Ma}$, wells II-2, IV-4 subside continuously till $190 \mathrm{Ma}$. The largest tectonic subsidence value is shown by well II-1, being $310 \mathrm{~m}$. The rest of the wells show rather much the same tectonic subsidence values, ranging from 20 to $100 \mathrm{~m}$. The majority of the wells show a pattern of less rapid subsidence during Sinemurian times

Fig. 6. Contour maps of tectonic subsidence (m) of: (A) Rotliegendes (Lower Permian, 290-256 Ma); (B) Zechstein (Upper Permian, 256-245 Ma), dashed line corresponding to tentative cross section in Fig. 7; (C) Triassic (245-209.5 Ma), dashed line corresponding to tentative cross section in Fig. 7; (D) Hettangian-Sinemurian (209.5-190 Ma); (E) Pliensbachian-Oxfordian (190-155 Ma); (F) Kimmeridgian-Tithonian (155-146 Ma); (G) Berriasian-Albian (146-97 Ma), area with relative continuous sedimentation in the Early Cretaceous $(E C)$, area with hardly any Early Cretaceous sedimentation (NOEC); (H) Cenomanian-Maastrichtian (97-65 Ma). Maps are interpolated from 1D results from individual stratigraphic sections, values are posted in the figure on the location of the sections. For location of studied area see Figs. 1 and 2. Numbers indicate amount of tectonic subsidence in time intervals. Negative values result from decreasing waterdepths in time interval. Symbols denote ratio of recorded duration of sedimentation in well and age interval of maps: $(0$, cross; $0-1 / 3$, diamond; $1 / 3-2 / 3$, box; $2 / 3-1$, circle). Please note that small artefacts in the contouring (not fully matching the observed values) can occur as a result of the contouring methodology, interpolating observed values on a regular grid. 


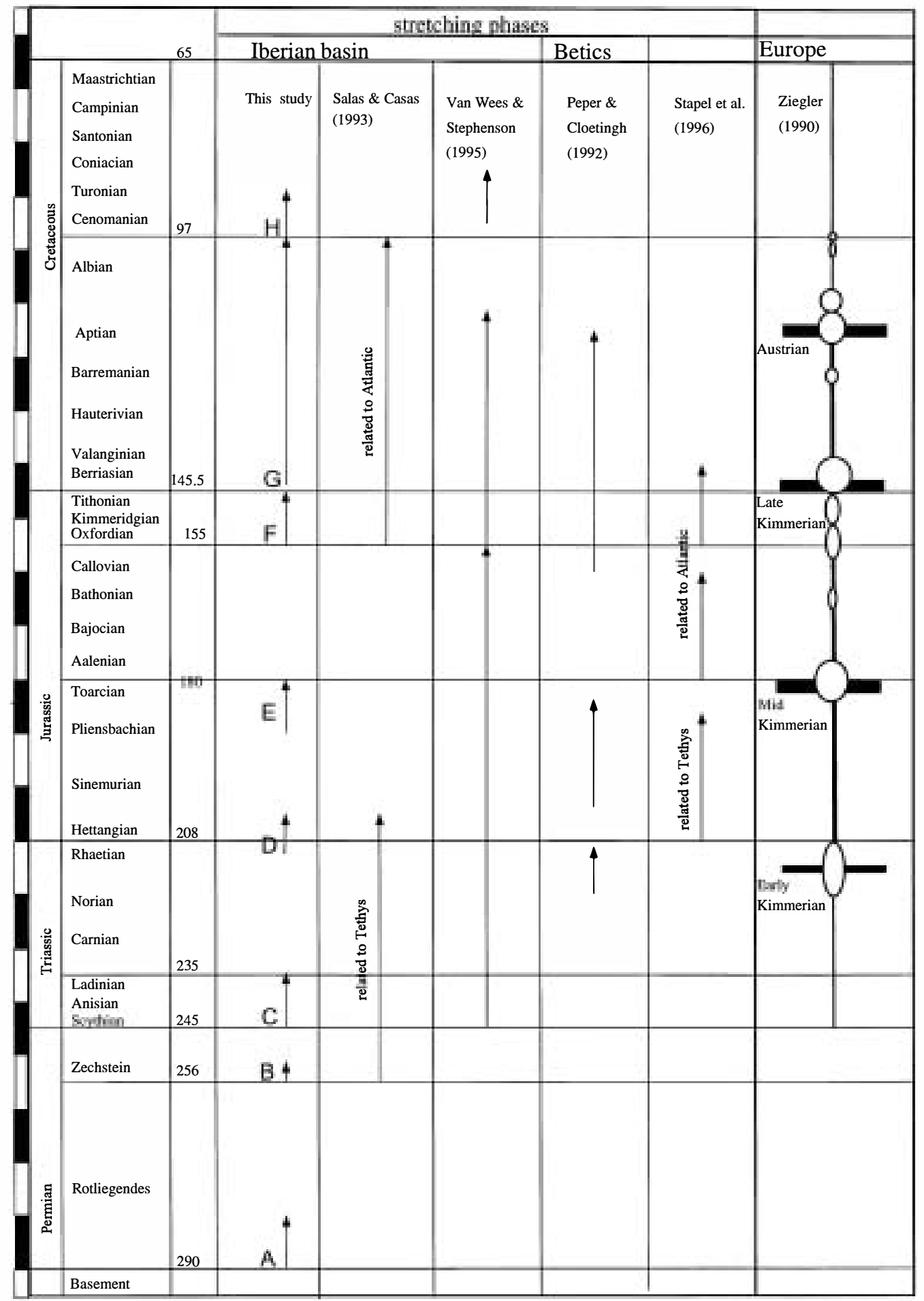

Fig. 8. Correlation of identified phases of rapid subsidence with other areas. 
(205-190 Ma, J3), indicating a postrift stage, though wells II-1, II-2, II-3 and IV-4 still show more rapid tectonic subsidence. Stratigraphic record is absent in wells I-1, I-4, III-1, VI-2, VI-3 and VI-4. Spatial patterns in rapid subsidence in Fig. 6 indicate a basin that takes a clear NE-SW orientation. Being based on complete stratigraphic successions for most of the wells, it clearly demonstrates a subsidence trend deviating considerably from the preceding Triassic. According to Salas and Casas (1993) extensional faulting takes place during the Rhaetian indicating that this phase of rapid subsidence may be explained by stretching. The inferred tectonic activity extending through $\mathrm{J} 2$ is also in agreement with the interpretation of Bernouilli and Jenkyns (1974) relating the basal breccia of J2 to early Liassic break-up platform in the framework of the Atlantic rift wrench system. Striking feature of the subsidence patterns is its NE-SW alignment parallel to the Betics. This phase corresponds very well to rapid subsidence observed in the Betic margin (Peper and Cloetingh, 1992; Fig. 8) and the Lusitanian Basin of western Portugal (Stapel et al., 1996; Fig. 8). Early Jurassic extensional tectonics, initiated in Triassic times have also been found in the Ebro Basin (Desegaulx and Moretti, 1998)

Pliensbachian-Oxfordian 190-155 Ma (J4-J6). A second period of Jurassic rapid tectonic subsidence takes place between 190 and $180 \mathrm{Ma}$ (J4J5), followed by decreasing subsidence rates in the Aalenian to Oxfordian (J6). Total subsidence values range from $30 \mathrm{~m}$ to $150 \mathrm{~m}$ in well III-3. It should be noted however that the inferred subsidence pattern is largely obscured by very differentiated subsidence and uplift for J6, marked in most wells by incomplete Aalenian to Oxfordian stratigraphy, characterised by hiatuses and uplift. As described above, well J6 in particular reflects tectonic activity, whereas J4 and J5 seem to be marked by relatively homogeneous sedimentation, lacking evidence for faulting. From the incomplete and complete wells a distinct E-W-trending Middle to Late Jurassic basin shape is apparent from Fig. 6, except for IV-4, which is marked by conspicuously low subsidence. This phase has not been taken into account in previous quantitative studies (Salas and Casas, 1993). However, subsidence data of Peper and Cloetingh (1992; Fig. 8) and Stapel et al. (1996; Fig. 8) indicating high subsidence rates, suggest a correlation with phases of regional tectonics recorded at the Iberian margins.

Kimmeridgian-Tithonian 155-146Ma (J7-J9). A phase of rapid tectonic subsidence is recorded mostly in the (south-)east, with rapid subsidence values ranging from 10 to $123 \mathrm{~m}$ in well IV-4, though most of the values are about $20-50 \mathrm{~m}$. Data are missing in the northwest and southeast. Spatial patterns in Fig. 6 indicate a preservation of the E-W-trending basin shape from the previous stage, overprinted by non-deposition in the west and subsidence in the (south-)east. This process, resulting in non-deposition and partial erosion in the northwest and southeast, may have started late in the previous phase, and most likely stopped at the earliest stages of the next phase, where sedimentation resumes in III-1 and III-2. The tectonically induced latest Jurassic destabilisation can be very well correlated to major tectonics in other areas along the Iberian Basin (Fig. 8), which correspond to the Kimmeridgian onset of the rotation of the Iberian Plate with respect to the European Plate (Dewey et al., 1973), associated with the opening of the Atlantic. Tectonic activity in the Iberian Ranges in this rotational setting extends into the Early Cretaceous up to the middle Albian (Álvaro et al., 1979; Salas and Casas, 1993). Extensional tectonics extending from the Kimmeridgian up to the Albian have also been observed in the Ebro Basin (Desegaulx and Moretti, 1998).

\subsection{Cretaceous}

Berriasian-Albian 146-97 Ma (K1-K10). Large spatial variations in tectonic subsidence mainly occur during the Early Cretaceous (146-112 Ma, K1K9) as is evident from the subsidence curves in Fig. 5. Relatively uniform subsidence exists during deposition of K1 (112-97 Ma). To outline the Early Cretaceous basin formation in Fig. 6, roughly a two-fold division can be made in the wells: those which are marked by a relatively continuous sequence in the Early Cretaceous containing considerable part of $\mathrm{K} 1-\mathrm{K} 9$ (indicated by EC) and those which are marked by a considerable hiatus in the Early Cretaceous (contain part of $\mathrm{K} 8-\mathrm{K} 10$, indicated by NOEC), but are marked by Late Cretaceous sedimentation (K10). The boundary between the EC and NOEC zones reflects the border of an Early Creta- 
ceous basin which developed in the southeast and is partly transected by a NW-SE-trending high indicating the control of NW-SE-trending basin faults on Early Cretaceous basin formation. The basin structure aligns very well with Triassic structures, suggesting reactivation. The eastern branch of the basin, corresponding to the Maestrat Basin, is deepest recording up to ca $250 \mathrm{~m}$ of subsidence. Here a remarkable Triassic reactivation is the relative high formed by well IV-4, which is characterised by relatively complete Early Cretaceous sedimentation and corresponds to the Triassic basement high in IV-4. The actual basin shape in the east of Fig. 6 is slightly obscured by incomplete stratigraphic records in wells III-4, V-2, VI-1 and VI-4 which lack most of the Cretaceous sediments as a result of Tertiary erosion. The inferred Early Cretaceous Basin shape corresponds very well with basin geometry from earlier studies (Rincón et al., 1983; Canérot, 1989). As we mentioned in the previous section the stratigraphic evolution is clearly marked by tectonics. Major tectonic activity marked by faulting and basin segmentation can be identified. for Kimmeridgian-middle Berriasian times (Aurell and Meléndez, 1993) or maybe Valanginian (Vilas et al., 1983) (K1-K3). A second main phase is identified for the Middle Albian sedimentation (K10) (Salas and Casas, 1993).

Rapid basin subsidence occurs simultaneously with relatively rapid subsidence in the Cameros Basin and basin formation in the Bay of Biscay (Rincón et al., 1983; Salomon, 1983; Hiscott et al., 1990).

Cenomanian-Maastrichtian 97-65 Ma (K11K14). Almost all the wells show a relative uniform increase in tectonic subsidence between $97 \mathrm{Ma}$ and $88.5 \mathrm{Ma}$. Excluded from this trend are wells III-4, V-2, VI-1 and VI-4 which lack most of the Cretaceous sediments as a result of Tertiary erosion. The subsidence patterns in Fig. 6 indicate a trend of increased subsidence from SE to NW, which corresponds very well with very gradual deepening towards the northwest during the Late Cretaceous observed from variations in depositional environments. No fault activity has been reported in the Iberian Basin for this phase (Salas and Casas, 1993) and the increased subsidence rates are relatively uniform, suggesting a eustatic origin. However, coeval rift activity observed to the south of Valencia indicates a tectonic origin (De Ruig, 1992). This may explain local deviations of the subsidence trend like observed in well I-3 in the northwest, which is marked by very low subsidence.

Effects of eustatic sea-level changes. As is evident from the subsidence analysis most phases of relatively rapid and differentiated subsidence (and uplift), alternating with periods of relative tectonic quiescence, can be well correlated with tectonic activity. Effects of eustatic sea-level variations, not incorporated in the subsidence analysis, may have played an important role in explaining some of the observed subsidence and uplift features, which do not relate to tectonic activity. Late Cretaceous eustatic sea-level rise may have contributed largely to the observed basin-wide subsidence. For other time periods, we believe the distribution of subsidence is mainly caused by tectonic events, since spatial variances in subsidence are large compared to regional subsidence and are clearly marked by fault activity as documented by previously mentioned studies. However, it should be noted that short-term sea-level fluctuations did play an important role in the sedimentation distribution. Most striking are Muschelkalk Facies sequences, which are marked by transgressive-regressive cycles. In a similar way basin-wide hiatuses, like in the late Callovian-early Oxfordian (Fig. 4) may be related to eustatic sea-level drop. The occurrence of such relatively short-term and relatively low-magnitude (compared to tectonics) sea-level fluctuations can not be easily detected from the subsidence data (Fig. 5). A possible exception may be Late Jurassic rapid subsidence, followed by rapid uplift in a period of $3 \mathrm{~m} . \mathrm{y}$. (e.g. sequence J7-J9) in wellsII-3 and III-3.

\section{Forward modelling of basin evolution}

The subsidence analysis in the previous section clearly shows that the Iberian Basin is characterized by a large number of pulsating phases of rapid tectonic subsidence, followed by slower subsidence rates. In order to establish a quantitative framework on the pulsating rift evolution of the lithosphere during Mesozoic basin formation, we quantified extension rates by forward modelling of tectonic subsidence, using a new 'automated' forward modelling technique (Van Wees et al., 1996b) which will be discussed shortly in the following. 


\subsection{Numerical model}

The forward modelling approach is based on lithospheric stretching assumptions (McKenzie, 1978; Royden and Keen, 1980). The factor $\delta$ was used for crustal stretching and $\beta$ for subcrustal stretching. For the thermal calculations, a 1D numerical finite-difference model was used, which allows incorporation of finite and multiple stretching phases. In order to handle a large number of wells and stretching phases in the forward model a numerical technique was developed (Van Wees et al., 1996b) which automatically finds best fit stretching parameters for (part of) the subsidence data. In this procedure the timing and duration of the rift phase must be specified, whereas best fit stretching values are found by searching for the minimum of the mean square root $F$ of the deviation in predicted and observed subsidence (Fig. 9), as a function of $\beta, \delta$ :

$F(\delta, \beta)=\frac{1}{\text { num }} \sqrt{\sum_{i=1}^{l=\text { num }}\left(s p_{\mathrm{p}, i}-s_{\mathrm{O}, i}\right)^{2}}$

where num is the number of subsidence data used in the fitting procedure and $s_{\mathrm{p}, i}, s_{\mathrm{o}, i}$ are predicted and observed subsidence values respectively. For a rift phase, either uniform lithospheric stretching $(\beta=\delta)$ (McKenzie, 1978) or two-layered stretching can be used $(\beta \neq \delta)$ (e.g. Royden and Keen, 1980). For uniform stretching, the solution of Eq. 1 requires that at least one observed subsidence data point is given after the onset of rifting, whereas the twolayered stretching requires at least two data points. For polyphase stretching, the fit is accomplished in sequential order. Initially, using an initial steady state thermal and compositional lithospheric configuration (cf. McKenzie, 1978), stretching parameters of the first phase are determined fitting data points in the synrift and postrift time interval up to the onset of the following phase. Subsequently, using the perturbed lithosphere configuration predicted at the onset of the second rifting phase, stretching parameters of this rift phase are determined using subsidence data from its synrift and postrift time interval up to the next rifting phase, etc.

In the solution procedure it is assumed that values for $\beta$ and $\delta$ can both be found in an interval from 0.2 to 10 . This covers the whole spectrum of realistic parameters for crustal and subcrustal thickening and thinning. In case of high tectonic uplift or subsidence in the postrift interval, it may be difficult to obtain a good fit of the subsidence, since subsidence and uplift rates are determined by the thermal relaxation of the subcrustal lithosphere. Maximum uplift and subsidence rates are for $\beta=0.2$ and $\beta=10$. Such predictions, implying extreme thermal perturbations of the subcrustal lithosphere, should be interpreted with great care.

Age (Ma)

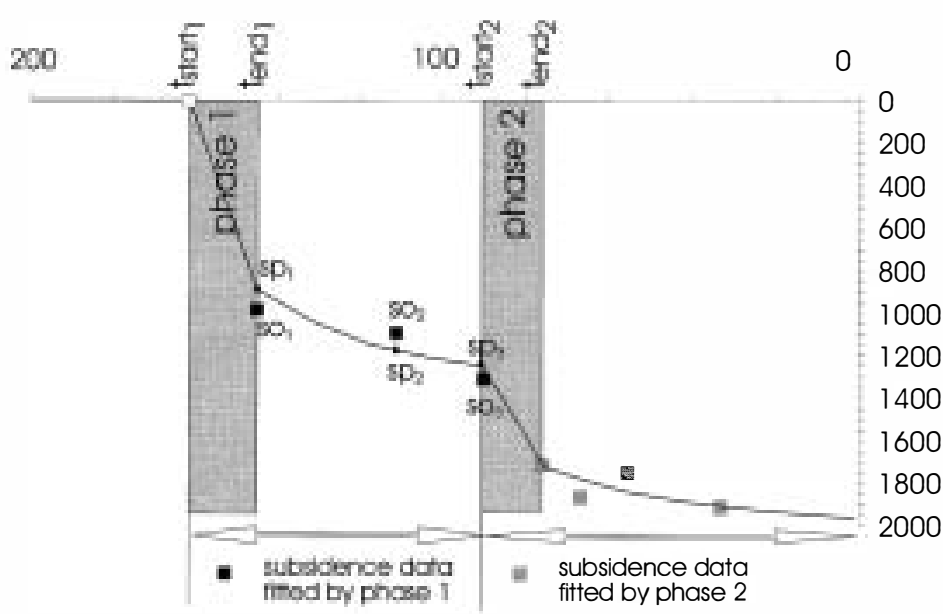

$E$
$E$
0
0
$\frac{0}{0}$
$\frac{0}{0}$
$\frac{0}{D}$
क

Fig. 9. Outline of forward modelling technique (from Van Wees et al., 1996b). 
Table 2

Parameters used to calculate tectonic subsidence in the forward model

\begin{tabular}{ll}
\hline Model parameter & Value \\
\hline Initial lithospheric thickmess & $110 \mathrm{~km}$ \\
Initial crustal thickmess & $32 \mathrm{~km}$ \\
Asthenospheric temperature & $1333^{\circ} \mathrm{C}$ \\
Thermal diffusivity & $1 \times 10^{-6} \mathrm{~m}^{2} \mathrm{~s}^{-1}$ \\
Surface crustal density & $2800 \mathrm{~kg} \mathrm{~m}^{-3}$ \\
Surface mantle density & $3400 \mathrm{~kg} \mathrm{~m}^{-3}$ \\
Water density & $1030 \mathrm{~kg} \mathrm{~m}^{-3}$ \\
Thermal expansion coefficient & $3.2 \times 10^{-5} \cdot \mathrm{C}$ \\
\hline
\end{tabular}

\subsection{Modelling procedure}

In the fitting procedure initial lithospheric configuration and thermal parameters are adopted as listed in Table 2. Initial lithospheric thickness was taken to be $110 \mathrm{~km}$, corresponding to the lithospheric thickness adopted in earlier studies in the same region (Morgan and Fernández, 1992; Van Wees and Stephenson, 1995). The initial crustal thickness corresponds to the present-day value beneath the Iberian Massif (Banda et al., 1983) and has also been adopted as initial value for this part of the basin by Salas and Casas (1993) and Van Wees and Stephenson (1995). The other parameters are taken from Van Wees and Stephenson (1995).

To fit the well data it was assumed that each observed phase of rapid tectonic subsidence should correspond with a stretching phase in the forward model. For these phases we initially adopted a two-layered stretching model of the lithosphere in order to obtain the highest degree of freedom in modelling subsidence data. In almost all the wells this model results in a good fit for the subsidence data. However, in this model subcrustal stretching factors $(\beta)$ are almost always equal or less than crustal stretching factors $(\delta)$. In some cases $\beta$ is less than one, resulting in lithospheric heating in the postrift phase, in agreement with observed very low post-rift subsidence or moderate uplift. Evidently $\beta$ values less then one are not reasonable in extensional tectonic settings. As a consequence the stretching phases modelled with the two-layered depth-dependent stretching model fails especially in cases where high values of tectonic uplift occur in a postrift phase (e.g. in wellII-5 between 18-155 Ma). These occurrences of uplift require some active mech- anism of uplift. Following Van Wees and Stephenson (1995), we adopt a thermal uplift mechanism. In the modelling this is implemented by setting crustal stretching $\delta$ to one and allowing $\beta$ to vary ( $\beta$-free model) in a period of $10 \mathrm{Ma}$ just before the onset of the next phase of stretching, while keeping $\delta$ fixed to one. The relatively small $\beta$ values $(\delta>\beta>1)$ may also be explaine in terms of postrift thermal uplift; we therefore prefer to adopt uniform stretching phases implementing subsequent thermal uplift similar to the cases in which $\beta<1$. An other reason we prefer to use the uniform stretching model instead of the two-layered depth-dependent model is that relatively large uncertainties are involved in estimating $\beta$ values for an individual postrift phases due to their relatively short duration (less than $30 \mathrm{Ma}$ ), and the small number of postrift data points associated with them. Fig. 10 illustrates the difference of the two-layered stretching model and uniform stretching model combined with the $\beta$-free model. Both models show a relatively good fit with observed subsidence data; however, as outlined above, the uniform stretching model combined with $\beta$-free results is favoured. As is evident from Fig. 10, a typical outcome of the uniform stretching model combined with the $\beta$-free model is the prediction of additional subsidence (deposition) followed by uplift (erosion). This pattern agrees very well with the fact that the base of the subsequent synrift stratigraphic sequence forms an erosional hiatus.

\subsection{Model results}

The forward modelled tectonic subsidence curves (Fig. 11) show a remarkably good fit with the subsidence data adopting a large number of stretching phases and phases of thermal uplift ( $\beta$-free, Fig. 10). In the Late Permian, Triassic and Jurassic and the Late Cretaceous, the stretching phases in the forward model occur very punctuated and simultaneously in almost all wells (256-254 Ma, 245-235 Ma, 209.5-205 Ma, 190-180 Ma, 155-150 Ma, 97-88.5 $\mathrm{Ma}$. These stretching phases correspond with the dark shaded areas identified in Fig. 5. In the Early Permian (290-270 Ma) stretching appears to be differentiated. In the Early Cretaceous (146-112 Ma) stretching is very differentiated and dischronous, resulting in locally more than one stretching phase to obtain a good fit. 


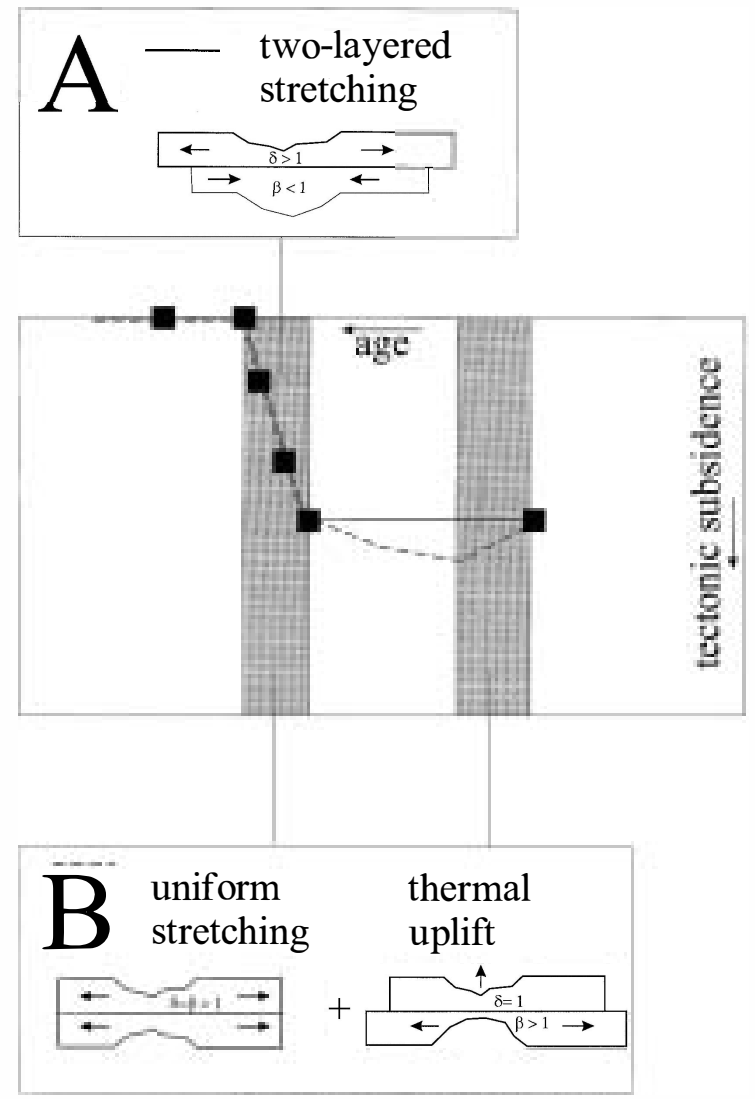

Fig. 10. Different model approaches to explain subsidence data marked by moderate postrift subsidence or uplift: (A) two-layered depth-dependent stretching model, (B) uniform stretching model combined with thermal uplift phase $\beta$-free.

The crustal stretching factors from the forward modelling have been plotted in map view in Fig. 12, for the same age intervals as in Fig. 6. For all episodes except the Early Cretaceous (Fig. 12G), the plotted values correspond to a single stretching phase. As can be expected, the crustal stretching patterns in Fig. 12, correspond very well to the subsidence patterns of corresponding age intervals in Fig. 6.

The stretching phase with clearly the largest stretching values is the Early Triassic phase (Fig. 12C) with values of $\delta$ of 1.019-1.116. All other phases are marked with lower-magnitude stretching values generally not exceeding 1.005 . These results, especially for the Triassic, agree well with the results of Van Wees and Stephenson (1995). However, the latter authors lumped the Jurassic and Cretaceous stretching phases in at most two phases, which in comparison with the results presented here are characterised by relatively higher stretching values and longer duration of the phases. This is a logical consequence of lumping short-lived pulsating rift events in a single rift phase. Estimates of Salas and Casas (1993) for crustal stretching values are much higher than our stretching values. They report average Mesozoic stretching of 1.31 in the Maestrat Basin. This relatively high value may be mostly contributed to a relatively thick Cretaceous sedimentation compared to the central area of the Iberian Basin. On the other hand the modelling technique they used for their estimates is not presented, hampering a full assessment for the cause of differences with our results. In general, the extremely low $(<1.005)$ but evident tectonic stretching phases clearly illustrate that the Iberian Basin evolved in an intraplate position. The large amount of tectonic phases we identify with a frequency of ca 10-50 m.y. agrees very well with the relatively large amount of short-lived tectonic pulses, cumulatively related to Tethys and Atlantic Plate reorganisations identified in compilations of Western Europe (e.g. encl. 52 in Ziegler, 1990; Fig. 8). This clearly shows that the Iberian Basin served as a sensitive recorder of far-field tectonic stresses of both the Tethys and the Atlantic.

In the model thermal uplift ( $\beta$-free, Fig. 10) has been incorporated especially in the Jurassic and Early Cretaceous in the following periods: ca. 220 $209.5 \mathrm{Ma}$, са. 200-190 Мa, ca. 165-155 Ma, ca. 145-135 Ma, ca. 122-112 Ma, ca. 112-97 Ma. In the forward modelling the adoption of these phases of thermal uplift and also of phases of very mild stretching may be subject to debate, since the modelling assumes local isostasy and neglects effects of sea-level changes. The flexural response during extensional faulting leads to flank uplift (Kooi et al., 1992; Van Wees and Cloetingh, 1994; Van Wees et al., 1996a). Such a process may have played a role during the Early Cretaceous, removing the need for thermal uplift in this period. Flexural effects interacting with intraplate stresses can explain regional patterns of relatively rapid basin subsidence and margin uplift in periods of tectonic quiescence (Cloetingh et al., 1985; Van Wees and Cloetingh, 

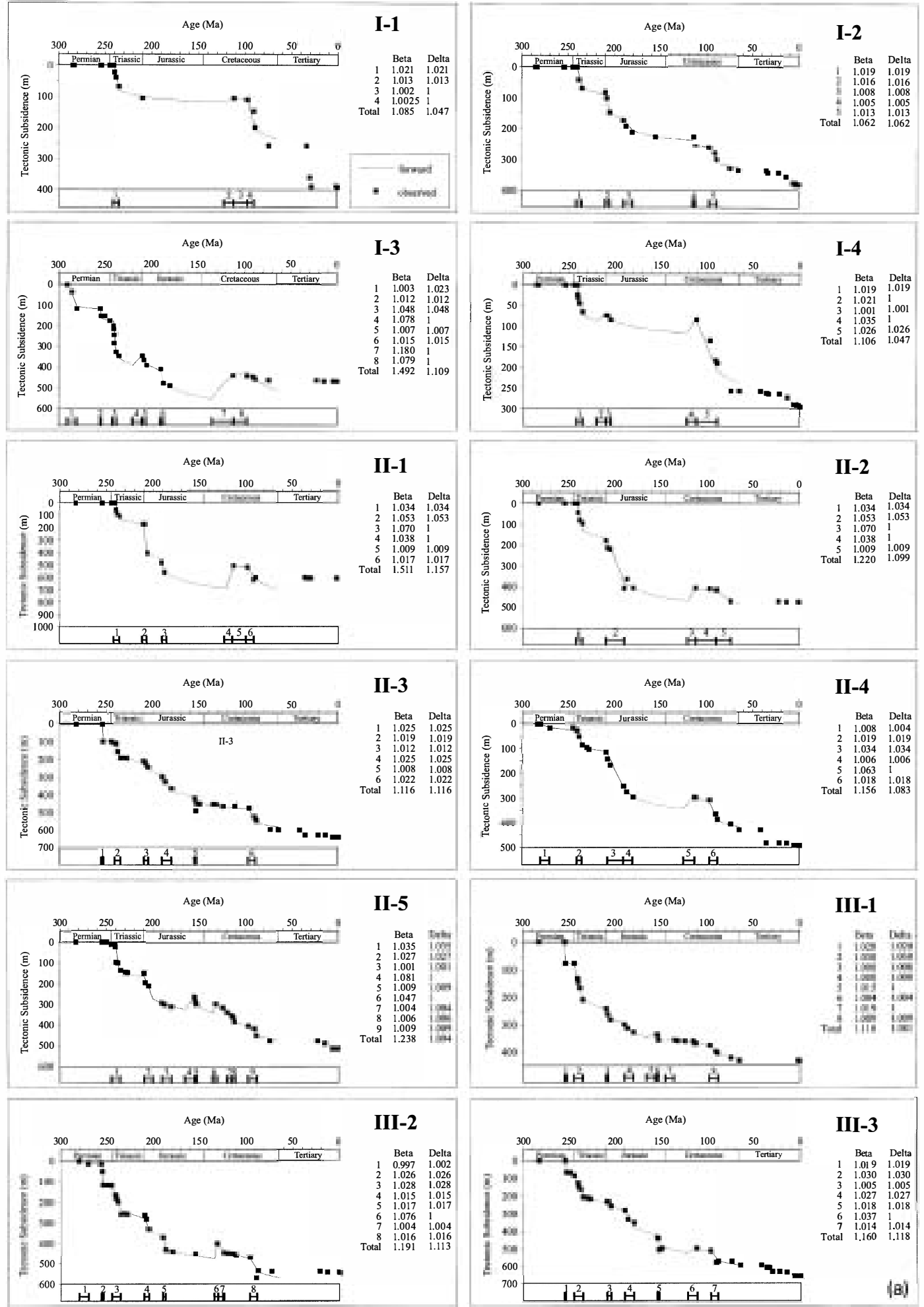

Fig. 11. Modelled subsidence curves for 24 stratigraphic sections and wells. For location of wells see Fig. 3. 


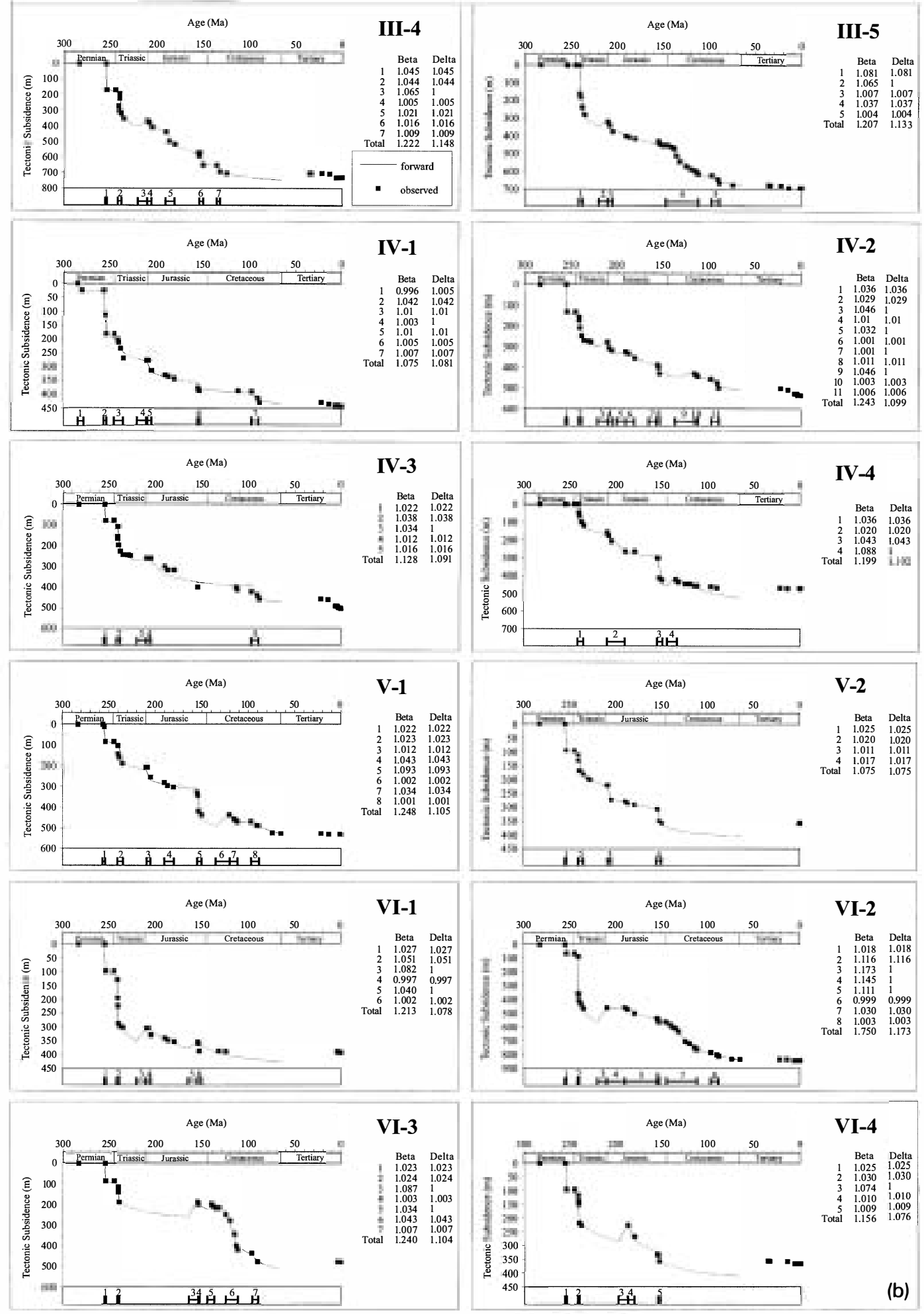

Fig. 11 (continued). 
(A) Crustal Stretching 290-256 Ma

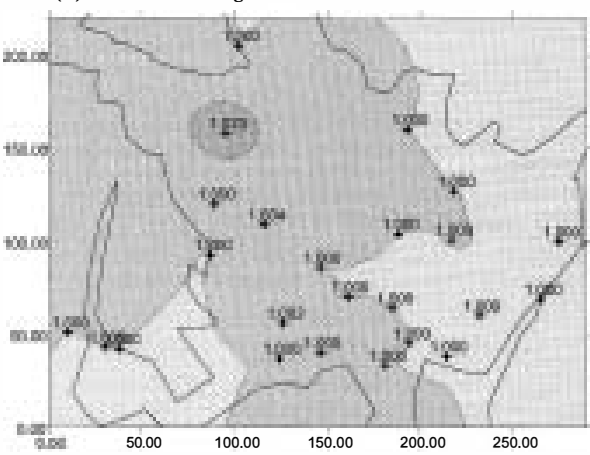

(C) Crustal Stretching 245-209.5 Ma

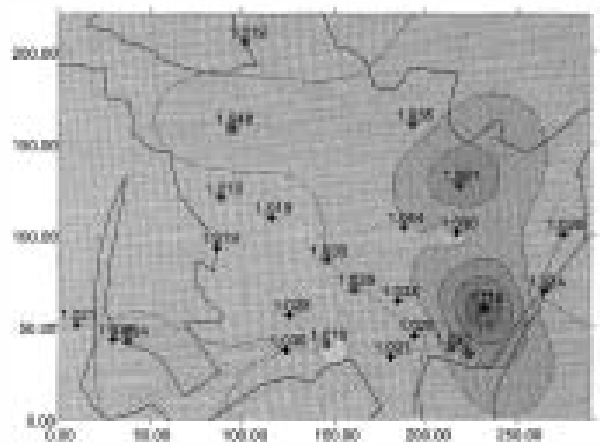

(E) Crustal Stretching 190-155 Ma

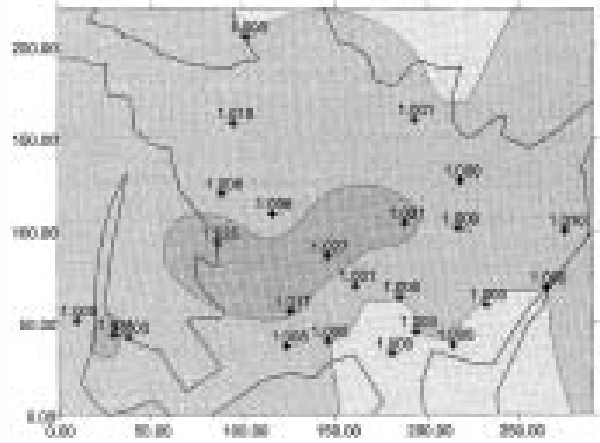

(G) Crustal Stretching 146-97 Ma

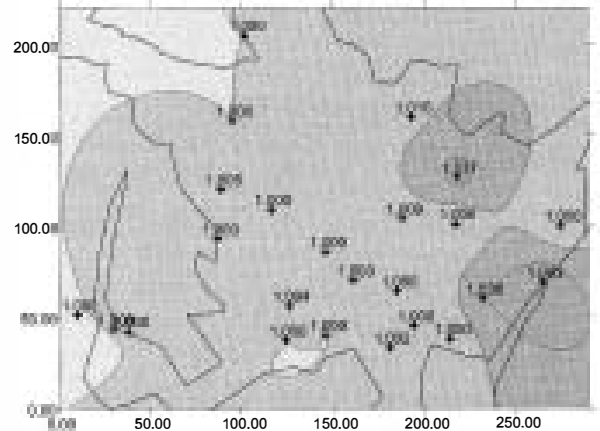

\section{(F) Cratal Strekting 156-2es Sto}

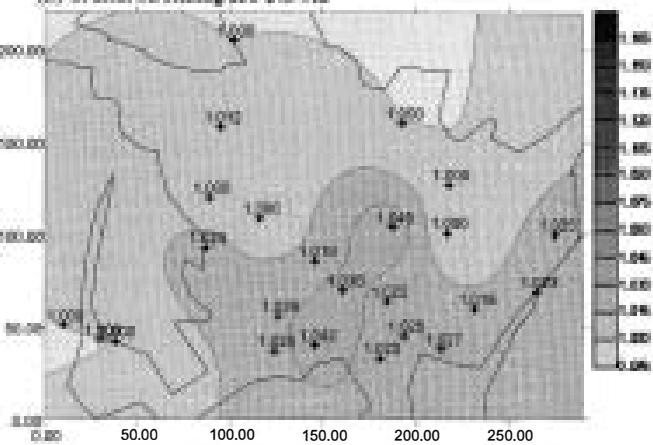

(D) Crustal Stretching 209.5-190 Ma
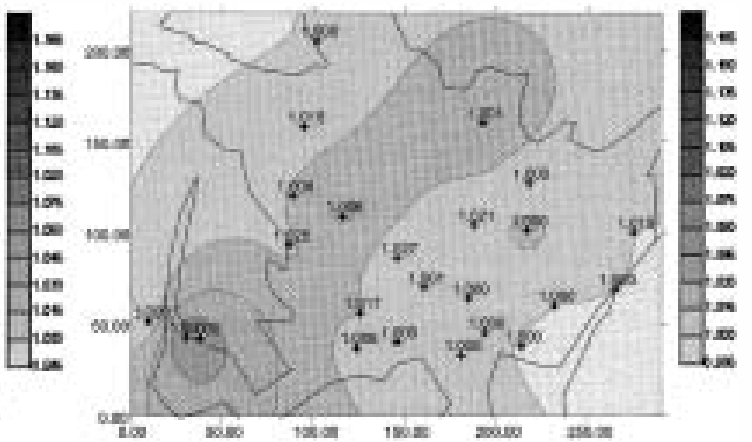

(F) Crustal Stretching 155-146 Ma
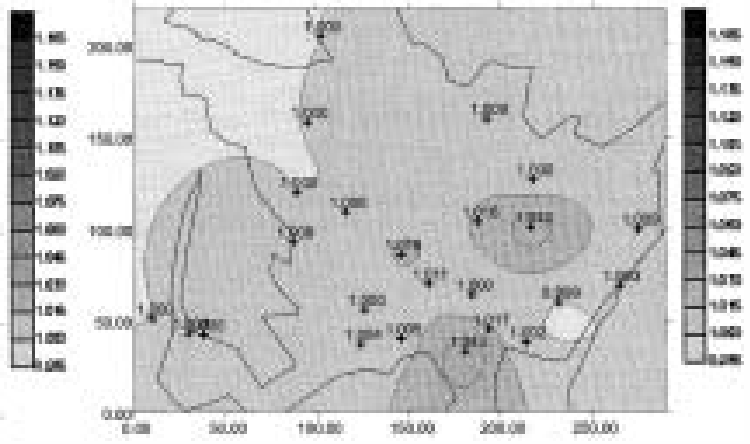

(H) Crustal Stretching 97-65 Ma

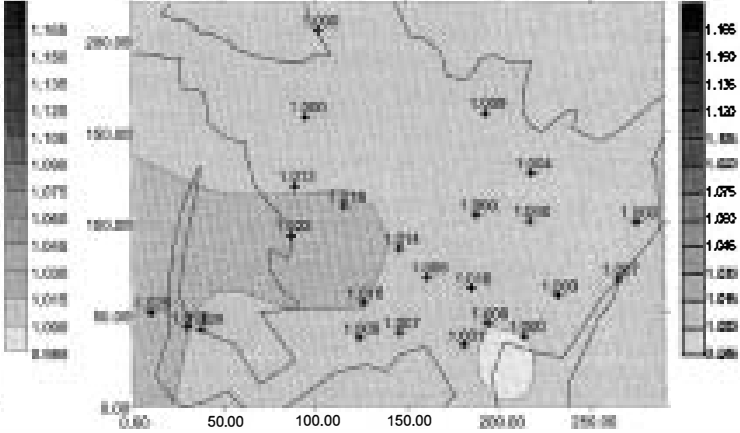




\section{Reconstructed moho depth at $65 \mathrm{Ma}$}

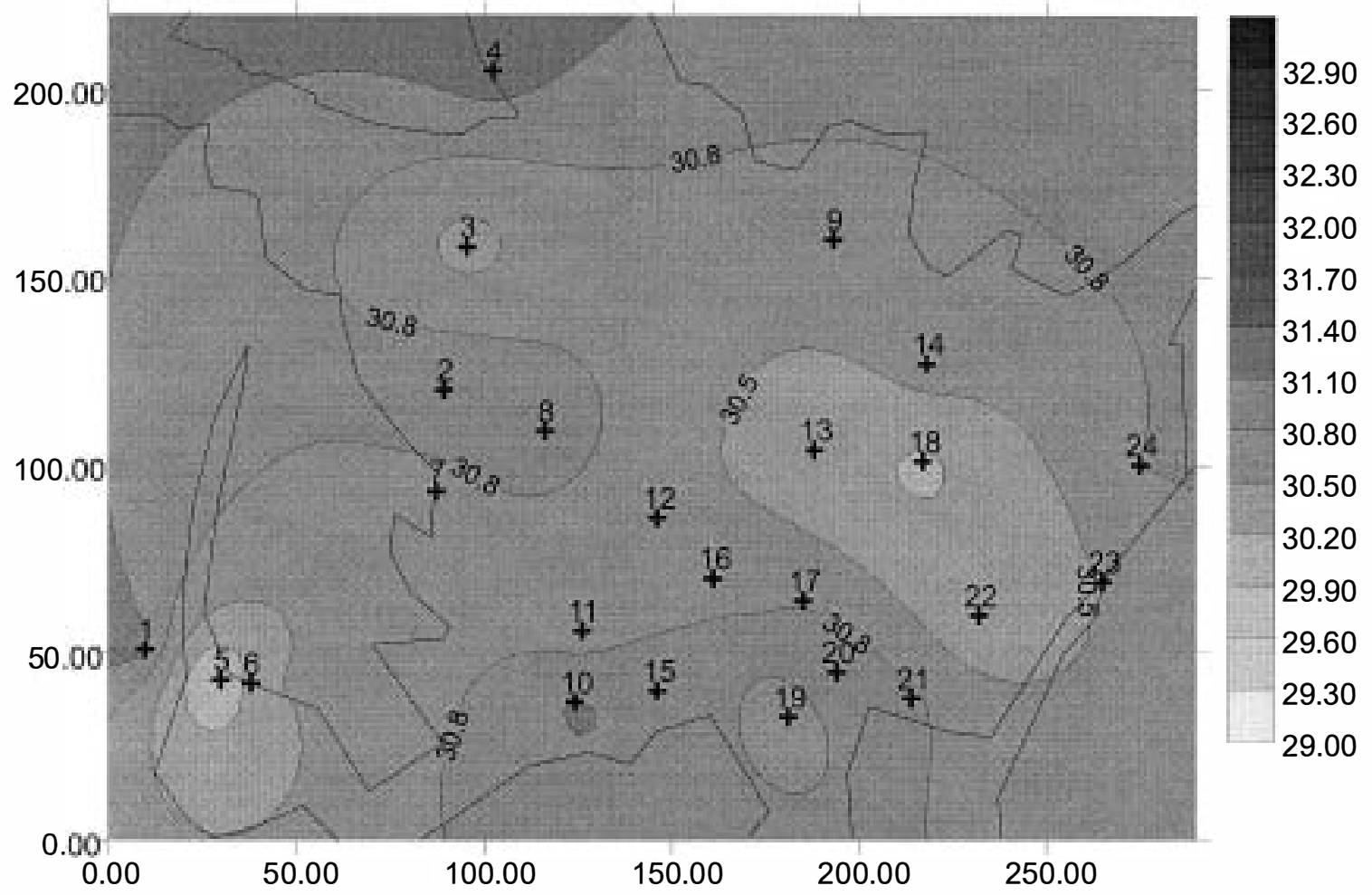

Fig. 13. Contour map of total crustal stretching. Map is interpolated from 1D results from individual stratigraphic sections; values are posted in the figure on the location of the sections.

1996). This process may have played a role in Early and Middle Jurassic times (209.5-190 Ma, 190$155 \mathrm{Ma})$, which is characterized by rapid subsidence marked by broad subsidence and uplift patterns. Sealevel changes may be responsible for regional uplift and subsidence but cannot explain spatial variations. As we mentioned earlier, regional subsidence related to a global sea-level rise (Haq et al., 1987) may explain partly the Late Cretaceous subsidence. For other time periods, we believe the distribution of subsidence is mainly caused by tectonic events, since spatial variances in subsidence are large com- pared to regional subsidence and agree with periods of tectonic activity.

\subsection{Total stretching}

In Fig. 13, we compiled a map of cumulative crustal stretching of the whole extensional history of the basin from Permian to Mesozoic. Again Fig. 13 shows clearly that stretching and associated crustal deformations are mild, in agreement with the intraplate setting of the Iberian Basin.

Fig. 12. Contour maps of lithospheric stretching $(\beta=\delta$ ) of: (A) Rotliegendes (Lower Permian, 290-256 Ma); (B) Zechstein (Upper Permian, 256-254) Ma; (C) L. Triassic-M. Triassic 245-235 Ma; (D) Hettangian-Sinemurian (209.5-190 Ma); (E) PliensbachianOxfordian (190-180 Ma); (F) Kimmeridgian-Tithonian (155-150 Ma); (G) Berriasian-Turonian (146-88.5 Ma). Maps are interpolated from $1 \mathrm{D}$ results from individual stratigraphic sections; values are posted in the figure on the location of the sections. For location of studied area see Figs. 1 and 2. 


\section{Conclusions}

The high-resolution backstrip analysis and forward modelling showed that the Mesozoic Iberian Ranges basin evolution is marked by a large number of rifting pulses, much more than documented by previous studies. The rift pulses are of low magnitude, very short lived and can be remarkably well correlated over the basin. This study indicates that an increased resolution in subsidence data leads to a better resolution in the tectonic signal. The automated modelling technique we used allows an efficient and very accurate assessment of temporal and spatial relations in lithospheric rift dynamics. Periods of rift activity correlate well with rift phases identified at other margins of the Iberian Plate, and the large number of identified phases agrees well with the full complexity of rift activity documented for northwestern Europe (e.g. Ziegler, 1990).

\section{Acknowledgements}

This is contribution 981202 of the Netherlands Research School of Sedimentry Geology (NSG).

\section{References}

Alónso, A., Floquet, M., Mas, R., Meléndez, A., Meléndez, N., Salomon, J., Vadot, J.-P., 1987. Modalités de la regression marine sur le détroit Ibérique (Espagne) à la fin du Crétacé. Mem. Geol. Univ. Dijon 11, 91-115.

Álvaro, M., Capote, R., Vegas, R., 1979. Un modelo evolucion geotectonica para la cadena Celtiberica. Acta Geol. Hisp. 14, 172-177

Arche, A., López-Gómez, J., 1989. Fluvial sedimentation during the early rifting phase in the southeastern Iberian Ranges. 4th Int. Conf. Fluvial Sedimentology, sitges, Barcelona, Field Guide, $88 \mathrm{pp}$.

Arche, A., López-Gómez, J., 1996. Origin of the PermianTriassic Iberian Basin, Central-Eastern Spain. Tectonophysics $266,443-464$

Aurell, M., 1991. Identification of systems tracks in low-angle carbonate ramps: example from the Upper Jurassic of the Iberian Chain (Spain). Sediment. Geol. 73, 101-115.

Aurell, M., Meléndez, A., 1993. Sedimentary evolution and sequence stratigraphy of the Upper Jurassic in the Central Iberian Chain, Northeast Spain. Spec. Publ. Int. Assoc. Sedimentol. 18, 343-368.

Banda, E., Udias, A., Mueller, S., Mezcua, J., Boloix, M., Gallart, J., Aparicio, A., 1983. Crustal structure beneath Spain from deep seismic sounding experiments. Phys. Earth Planet. Inter. 31, 277-280.

Bemouilli, D., Jenkyns, H.C., 1974. Alpine, Mediterranean and Central Atlantic Mesozoic facies in relation to the early evolution of the Tethys. In: Dott, R.H., Shaver, R.H. (Eds.), Modem and Ancient Geosynclinal Sedimentation. Soc. Econ. Paleontol. Mineral., Spec. Publ. 19, 129-160.

Bond, G., Kominz, M.A., 1984. Construction of tectonic subsidence curves for the Early Paleozoic miogeocline, southem Canadian Rocky Mountains: implications for subsidence mechanisms, age of break up, and crustal thinning. Geol. Soc. Am. Bull. 95, 155-173.

Canérot, J., 1974. Recherches géologiques aux confins des chaînes Iberique et Catalane (Espagne). Ph.D. Thesis, Univ. Toulouse, ENADIMSA, 5 (2), 517 pp.

Canérot, J., 1989. Distensions mesozoiques et halocinese dans les Iberides (Espagne). Bull Soc. Geol. Fr. 5, 905-912

Canérot, J., Cugny, P., Pardo, G., Salas, R., Villena, J., 1982. Ibérica Central-Maestrazgo. In: E1 Cretácico de España. Universidad Complutense de Madrid, pp. 273-344

Cloetingh, S., McQueen, H., Lambeck, K., 1985. On a tectonic mechanism for regional sea level variations. Earth Planet. Sci. Lett. $75,157-166$.

De Ruig, M.J., 1992. Tectono-Sedimentary Evolution of the Prebetic Fold Belt of Alicante (SE SPAIN): A Study of Stress Fluctuations and Foreland Basin Deformation. Ph.D. Thesis, Vrije Universiteit, Amsterdam, $207 \mathrm{pp}$.

Desegaulx, P., Moretti, I., 1998. Subsidence history of the Ebro Basin. J. Geodyn. 10, 9-24

Dewey, J.F., Pitman, W.C., III, Ryan, W.B.F., Bonnin, J., 1973. Plate tectonics and the evolution of the Alpine System. Geol. Soc. Am. Bull. 84, 3137-3180

Fernández-López, S., Gómez, J.J., 1990. Facies aalenienses y bajocienses, con evidencias de emersión y carstificación, en el sector central de la Cuenca Ibérica. Cuad. Geol. Iber. 14, 67-112

Floquet, M., 1991. La plate-forme north-castillane au Crétacé supérieur (Espagne). Arrier-pays ibérique de la marge passive basco-cantabrique. Sédimentation et vie. Ph.D. Thesis, Univ. Dijon, Mem. Géol. Univ. Dijon 14 (2), 925 pp.

García, A., Segura, M., Gacía-Hidalgo, J.F., 1996. Sequences, cycles and hiatuses in the Upper Albian-Cenomanian of the Iberian Ranges (Spain): a cyclostratigraphic approach. Sediment. Geol. 103, 175-200.

Gómez, J.J., 1979. E1 Jurásico en facies carbonatadas del sector levantino de la Cordillera Ibérica. Seminar. Estratigr. 4, 683 pp.

Gómez, J.J., Goy, A., 1979. Las unidades litoestratigráficas del Jurásico medio y superior en facies carbonatadas del sector levantino de la Cordillera Ibérica. Estud. Geol. 35, 569-598.

Goy, A., Martínez, G., 1990. Biozonación del Toarciense en el área de la Almunia de Doña Godina-Ricla (sector central de la Cordillera Ibérica). Cuad. Geol. Iber. 14 (2), 11-54.

Goy, A., Suarez Vega, L.C., 1983. E1 Jurásico. In: Geologia de España. Libro jubilar J.M. Rios, 2. Inst. Geol. Minero España, Madrid, pp. 62-79.

Goy, A., Gómez, J.J., Yébenes, A., 1976. E1 Jurásico de la Rama 
Castellana de la Cordillera Ibérica (Mitad Norte), I. Unidades litoestratigráficas. Estud. Geol. 32, 391-423.

Haq, B., Hardenbol, J., Vail, P.R., 1987. Chronology of ftuctuating sealevels since the Triassic (250 million years ago to present). Science 235, 1156-1167

Harland, W.B., Amnstrong, R.L., Cox, A.V., Craig, L.E., Smith, A.G., Smith, D.G., 1990. A Geologic Time Scale. Cambridge Univ. Press, Cambridge, 263 pp.

Hiscott, R.N., Wilson, R.C.L., Gradstein, F.M., Pujalte, V., Gracia-Mondejar, J., Boudreau, R.R., Wishart, H.A., 1990. Comparative stratigraphy and subsidence history of Mesozoic rift basins of North Atlantic. Bull. Am. Assoc. Pet. Geol. 74, 676.

Kooi, H., Cloetingh, S., Bumus, J., 1992. Lithospheric necking and regional isostasy at extensional basins, 1. Subsidence and gravity modelling with an application to the Gulf of Lions Margin (SE France). J. Geophys. Res. 97 (B12), 1755317572.

López-Gómez, J., Arche, A., 1992a. Las unidades litostratigráficas del Pérmico y Triásico Inferior y Medio en el sector SE de la Cordillera Ibérica. Estud. Geól. 48, 122-143.

López-Gómez, J., Arche, A., 1992b. Paleogeographical significance of the Röt (Anisian, Triassic) Facies (Marines, Clays, Muds and Marls Fm.), Iberian Ranges, eastem Spain. Palaeogeogr., Palaeoclimatol., Palaeoecol. 91, 347-361.

López-Gómez, J., Arche, A., 1993. Sequence stratigraphy analysis and paleogeographic interpretation of the Bundtsandstein and Muschelkalk Facies (Permo-Triassic) in the Iberian Ranges. Palaeogeogr., Palaeoclimatol., Palaeoecol. 103, 179201.

López-Gómez, J., Arche, A., 1995. E1 Permico y el Triasico del Levante espanol. Caracteristicas principales y consideraciones paleogeograficas. Cuad. Geol. Iber. 19, 201-234.

López-Gómez, J., Arche, A., 1997. The Upper Permian Boniches Conglomerates Formation: evolution from alluvial fan to $\mathrm{ftu}-$ vial system environments and accompanying tectonic and climatic controls in the southeast Iberian Ranges, central Spain. Sediment. Geol. 114, 267-294

Martinez del Ohno, W., 1996. Estratigrafia secuencial en el Jurasico del Prebetico y Golfo de Valencia a partir de sondeos profiudos. Geogaceta 20 (1), 108-111.

McKenzie, D.P., 1978. Some remarks on the development of sedimentary basins. Earth Planet. Sci. Lett. 40, 25-31.

Meléndez, N., 1982. Presencia de una 'discordancia cartográfica' intrabarremiense en la Cordjllera Ibérica occidental (provincia de Cuenca). Estud. Geol. 38, 51-54.

Meléndez, N., 1983. El Cretácico de la región de Cañete-Rincón de Ademuz (provincias de Cuenca y Valencia). Seminar. Estratigr., Ser. Monogr. 9, 242 pp.

Morgan, P., Fernández, M., 1992. Neogene vertical movements and constraints on extension in the Catalan Coastal Ranges, Iberian Peninsula, and the Valencia trough (western Mediterranean). Tectonophysics 203, 185-201.

Muñoz, J.A., 1992. Evolution of a continental collision belt: ECORS-Pyrenees crustal balanced cross-section. In: McClay, K.R. (Ed), Thrust Tectonics. Chapman and Hall, London, pp. 235-246.
Peper, T., Cloetingh, S., 1992. Lithosphere dynamics and tectono-stratigraphic evolution of the Mesozoic Betic rifted margin (southeastem Spain). Tectonophysics 203, 345-361.

Ramos, A., 1979. Estratigrafía y paleogeografía del Pérnico y Triásico del oeste de Molina de Aragón (prov. de Guadalajara). Seminar. Estratigr. 6, 313 pp.

Rincón, R., Vilas, L., Arias, C., García-Quintana, A., Mas, J.R., Alónso, A., Méléndez, N., 1983. El Cretacico de las Cordilleras intermedias y borde de la Meseta. In Geología de España, Libro Jubilar J.M. Rios, 2. Inst. Geol. Minero España, Madrid, pp. 79-103.

Roca, E., Guimerà, J., 1992. The Neogene structure of the eastem Iberian margin: structural constrains of the crustal evolution of the Valencia Through (western Mediterranean). In: Banda., E., Santanach, P. (Eds.), Geology and Geophysics of the Valencia Trough, Western Mediterranean. Tectonophysics 203, 203-218.

Roest, W.P., Srivastava, S.P., 1991. Kinematics of the plate boundaries between Eurasia, Iberia, and Africa in the North Atlantic from the Late Cretaceous to the present. Geology 19, 613-616.

Royden, L., Keen, C.E., 1980. Rifting process and themal evolution of the continental margin of eastem Canada determined from subsidence curves. Earth Planet. Sci. Lett. 51, 343-361.

Ruiz, G., 1993. Secuencias deposicionales en las facies terrigenas del Cretácico en la región del Alto Tajo (Cordillera Ibérica), provincias de Guadalajara y Cuenca. Geogaceta 13, 11 -112.

Salas, R., 1987. El Malm i el Cretaci inferior entre el Massís de Garraf i la Serra de'espadà. Anàlisi de conca. Ph.D. Thesis, Univ. Barcelona, 345 pp.

Salas, R., Casas, A., 1993. Mesozoic extensional tectonics, stratigraphy and crustal evolution during the Alpine cycle of the eastem Iberian Basin. Tectonophysics 228, 33-56.

Salas, R., Martin-Closas, C., 1995. El Cretácico Inferior del Nordeste de Iberia. Field Guide. III Coloquio del Cretácico de España, Morella, 1991, 53 pp.

Salomon, J., 1983. Les phases 'fosse' dans 1'histoire du Bassin de Soria (Espagne du nord) au Jurassique Supérieure-Crétacée Inférieure. Bull. Cent. Rech. Explor. Prod. Elf Aquitaine 7, 399-407.

San Román, J., Aurell, M., 1992. Paleogeographical significance of the Triassic-Jurassic unconformity in the north Iberian Basin (Sierra del Moncayo, Spain). Palaeogeogr., Palaeoclimatol., Palaeoecol. 99, 101-117.

Sclater, J.G., Christie, P.A.F., 1980. Continental Stretching: An explanation of the post-Mid-Cretaceous subsidence of the Central North Sea Basin. J. Geophys. Res. 85, 3711-3739.

Sopeña, A., López-Gómez, J., Arche, A., Pérez-Arlucea, M., Ramos, A., Virgili, C., Hernándo, S., 1988. Pernian and Triassic rift basins of the Iberian Peninsula, In: Manspeizer, W. (Ed.) Triassic-Jurassic Rift.ing, Part B. Elsevier, Amsterdam, pp. 757-786.

Stapel, G., Cloetingh, S., Pronk, B., 1996. Quantitative subsidence analysis of the Mesozoic evolution of the Lusitanian basin (W Iberian margin). Tectonophysics 266, 493-507.

Steckler, M.S., Watts, A.B., 1978. Subsidence of the Atlantic- 
type continental margin off New York. Earth Planet. Sci. Lett. 41, 1-13.

Thierry, J., Wilde, S., 1990. Bathonian-Callovian (Middle Jurassic)ammonite faunas of North-west Iberian Ranges: biostratigraphy and palaeobiogeography. Cuad. Geol. Iber. 14, 143156.

Van Wees, J.D., Cloetingh, S., 1994. A finite difference teclınique to incorporate spatial vanations in rigidity and planar faults into 3-D models for lithospheric flexure. Geophys. J. Int. 117, 179-195.

Van Wees, J.D., Cloetingh, S., 1996. 3D flexure and intraplate compression in the North Sea Basin. Tectonophysics 266, 243-359.

Van Wees, J.D., Stephenson, R.A., 1995. Quantitative modelling of basin and rheological evolution of the Iberian Basin (Central Spain): implications for lithospheric dynamics of intraplate extension and inversion. Tectonophysics 252, 163-178.

Van Wees, J.D., De Jong, K., Cloetingh, S., 1992. Two-dimensional $P-T-t$ modelling and the dynamics of extension and inversion in the Betic Zone (SE Spain). Tectonophysics 203, 305-324.

Van Wees, J.D., Cloetingh, S., de Vicente, G., 1996a. The role of pre-existing weak zones in basin evolution: constraints from 2D finite element and 3D flexure modelling. Geol. Soc. London Spec. Publ. 99, 297-320.

Van Wees, J.D., Stephenson, R.A., Stovba, S.M., Shymanovskyi, V.A., 1996b. Tectonic vanation in the Dniepr-Donets Basin from automated modelling of backstripped subsidence curves. Tectonophysics 268, 257-280.

Vegas, R., Banda, E., 1982. Tectonic framework and Alpine evolution of the Iberian Peninsula. Earth Evolut. Sci. 4, 320343.

Viallard, P., 1973. Recherches sur le cycle alpin dans la Chaine Iberique sudoccidentale. Ph.D Thesis, Université Paul Sabatier, Toulouse, $445 \mathrm{pp}$

Vilas, L., Alonso, A., Arias, C., García, A., Mas, J.R., Rincón, R., Meléndez, N., 1983. The Cretaceous of the Southwestem Iberian Ranges (Spain). Zitteliana 10, 245-254.

Wilde, S., 1990. The Bathonian and Callovian of the Northwest-Iberian Range: stages of facial paleogeographical differentiation on the epicontinental platform. Cuad. Geol. Iber. 14, 113-142.

Ziegler, P.A., 1990. Geological Atlas of Westem and Central Europe, 2nd ed. Geol. Soc. London/Shell Internationale Petroleum Maatschappij, London, $239 \mathrm{pp}$. 